\title{
Modelling the climatic drivers determining photosynthesis and carbon allocation in evergreen Mediterranean forests using multiproxy long time series
}

\author{
G. Gea-Izquierdo ${ }^{1}$, F. Guibal ${ }^{2}$, R. Joffre ${ }^{3}$, J. M. Ourcival ${ }^{3}$, G. Simioni ${ }^{4}$, and J. Guiot ${ }^{1}$ \\ ${ }^{1}$ CEREGE UMR7330, CNRS/Aix-Marseille Université, Europole de l'Arbois, BP 8013545 , \\ Aix-en-Provence CEDEX 4, France \\ ${ }^{2}$ IMBE, CNRS/Aix-Marseille Université, UMR7263 Europole de l'Arbois, BP 8013545, \\ Aix-en-Provence CEDEX 4, France \\ ${ }^{3}$ Centre d'Ecologie Fonctionnelle et Evolutive CEFE, UMR5175, CNRS, Université de Montpellier, \\ Université Paul-Valéry Montpellier, EPHE, 1919 Route de Mende, 34293 Montpellier CEDEX 5, France \\ ${ }^{4}$ Ecologie des Forêts Méditerranéennes, INRA UR629, Domaine Saint Paul, 84914 Avignon CEDEX 9, France \\ Correspondence to: G. Gea-Izquierdo (gea-izquierdo@cerege.fr; guigeiz@gmail.com)
}

Received: 28 December 2014 - Published in Biogeosciences Discuss.: 6 February 2015

Revised: 10 May 2015 - Accepted: 18 May 2015 - Published: 17 June 2015

\begin{abstract}
Climatic drivers limit several important physiological processes involved in ecosystem carbon dynamics including gross primary productivity (GPP) and carbon allocation in vegetation. Climatic variability limits these two processes differently. We developed an existing mechanistic model to analyse photosynthesis and variability in carbon allocation in two evergreen species at two Mediterranean forests. The model was calibrated using a combination of eddy covariance $\mathrm{CO}_{2}$ flux data, dendrochronological time series of secondary growth and forest inventory data. The model was modified to be climate explicit in the key processes addressing the acclimation of photosynthesis and the pattern of $\mathrm{C}$ allocation, particularly to water stress. It succeeded in fitting both the high- and the low-frequency response of stand GPP and carbon allocation to stem growth. This would support its capability to address both C-source and C-sink limitations. Simulations suggest a decrease in mean stomatal conductance in response to a recent enhancement in water stress and an increase in mean annual intrinsic water use efficiency (iWUE) in both species during the last 50 years. However, this was not translated into a parallel increase in ecosystem water use efficiency (WUE). The interannual variability in WUE closely followed that in iWUE at both sites. Nevertheless, long-term decadal variability in WUE followed the long-term decrease in annual GPP match-
\end{abstract}

ing the local trend in annual precipitation observed since the late 1970s at one site. In contrast, at the site where long-term precipitation remained stable, GPP and WUE did not show a negative trend and the trees buffered the climatic variability. In our simulations these temporal changes were related to acclimation processes at the canopy level, including modifications in LAI and stomatal conductance, but also partly related to increasing $\left[\mathrm{CO}_{2}\right]$ because the model includes biochemical equations where photosynthesis is directly linked to $\left[\mathrm{CO}_{2}\right]$. Long-term trends in GPP did not match those in growth, in agreement with the $\mathrm{C}$-sink hypothesis. The model has great potential for use with abundant dendrochronological data and analyse forest performance under climate change. This would help to understand how different interfering environmental factors produce instability in the pattern of carbon allocation and, hence, the climatic signal expressed in tree rings.

\section{Introduction}

Global change challenges forest performance because it can enhance forest vulnerability (IPCC, 2013). Trees modify multiple mechanisms on different scales to tackle environmental stress, including changes in photosynthesis and car- 
bon allocation within plants (Breda et al., 2006; Niinemets, 2007; Chen et al., 2013). Many factors affect the different physiological processes driving forest performance. Among them, the net effect of the rising $\mathrm{CO}_{2}$ mixing ratio $\left(\left[\mathrm{CO}_{2}\right]\right)$ and climate change is meaningful when determining the forests' capacity of acclimation to enhanced xericity (Peñuelas et al., 2011; Keenan et al., 2011; Fatichi et al., 2014). Forest process-based models have been developed to mimic these mechanisms. They can include different levels of complexity but generally implement calculations of leaf photosynthesis upscaled to the canopy and carbon allocated to different plant compartments (Le Roux et al., 2001; Schaefer et al., 2012; De Kauwe et al., 2013). Although there is evidence that the tree performance depends to some extent on stored carbohydrates (Breda et al., 2006; McDowell et al., 2013; Dickman et al., 2015), these models have received some criticism when used to understand plant performance in response to climate change. This is in part because they are C-source oriented, therefore can exhibit certain limitations to represent the C-sink hypothesis (i.e. that growth rates are limited by environmental factors such as water stress, minimum temperature or nutrient availability rather than by carbohydrate availability) and address dysfunctions related to the tree hydraulics (Millard et al., 2007; Breshears et al., 2009; Sala et al., 2012; Körner, 2013; McDowell et al., 2013; Fatichi et al., 2014).

Complex process-based models benefit from multiproxy calibration, particularly when such data are applied on different spatio-temporal scales (Peng et al., 2011). The temporal scale can be approached using time growth series of dendrochronological data. However, the analysis of the past always adds uncertainties related to the influence of unknown stand conditions to properly scale productivity. Flux data, including stand productivity, can be estimated using the eddy covariance technique (Baldocchi, 2003). These data overcome many of the limitations of dendroecological data (e.g. intra-annual resolution, control of stand conditions and scaling of net productivity), but they lack their spatial and temporal coverage. Thus, $\mathrm{CO}_{2}$ flux data can be used to implement unbiased models of canopy photosynthesis and can then be combined with dendroecological data to study how carbon is allocated to stem growth as a function of environmental forcing (Friedlingstein et al., 1999; Chen et al., 2013, McMurtrie and Dewar, 2013).

Mechanistic models can also be used to analyse the environmental factors determining instability in the climategrowth response (D'Arrigo et al., 2008). Different processbased models have been applied with dendroecological data used either in forward or inverse mode (see Guiot et al., 2014, for a review). Among these models, the process-based model MAIDEN (Modeling and Analysis In DENdroecology). (Misson, 2004) was originally developed using dendroecological data. The model explicitly includes $\left[\mathrm{CO}_{2}\right]$ to calculate photosynthesis (hence its influence on carbon allocation) and includes a carbohydrate storage reservoir, this be- ing one of its strengths compared to other models (Vaganov et al., 2006; Sala et al., 2012; Guiot et al., 2014). It has been previously employed to analyse growth variability in one temperate and two Mediterranean species (Misson et al., 2004; Gaucherel et al., 2008) and recently, in inverse mode (also including $\mathrm{C}$ and $\mathrm{O}$ stable isotopes), to reconstruct past climate (Boucher et al., 2014). However, it requires further development to ensure that it provides unbiased estimates of forest productivity and assesses uncertainties in the response of trees to climatic variability on a greater spatial scale at the regional level. In particular, its parameterization would need improvement if the model is applied to assess how climate modulates forest performance and the pattern of $\mathrm{C}$ allocation within plants (Niinemets and Valladares, 2004; Fatichi et al., 2014).

In this study we use multiproxy data to develop a processbased model and investigate how evergreen Mediterranean forests have modified stand photosynthesis and carbon allocation in response to interacting climatic factors and enhanced $\left[\mathrm{CO}_{2}\right]$ in the recent past. The first objective was to develop a process-based model based on MAIDEN (Misson, 2004). Within the new version of the model, photosynthesis, carbon allocation, canopy turnover and phenology are now calculated using climate-explicit functions with a mechanistic basis. The model is adapted to give unbiased estimates of canopy photosynthesis and stem growth using instrumental data. Specifically, within the new model formulation, (1) photosynthesis is penalized by prolonged water stress conditions through reductions in leaf area index (LAI) and maximum photosynthetic capacity; (2) the pattern of carbon allocation is directly determined by soil water content (i.e. water stress) and temperature through nonlinear relationships; (3) these relationships can be contrasting for different phenophases and affect photosynthesis and the pattern of $\mathrm{C}$ allocation independently. Once the model was developed, a second objective was to analyse how $\left[\mathrm{CO}_{2}\right]$ and climatic variability affect the temporal instability in annual forest productivity, water use efficiency and carbon allocation. We hypothesize that they will exhibit differences in their long-term variability in relation to recent climate change driven by different functional acclimation processes within trees.

\section{Material and methods}

\subsection{Study sites and climatic data}

The study sites were two evergreen Mediterranean monitored forests in Southern France where $\mathrm{CO}_{2}$, water vapour and energy fluxes are measured using the Eddy covariance technique (Baldocchi, 2003). Both sites are included in FLUXNET (http://fluxnet.ornl.gov/). The first site, Fontblanche $\left(43.2^{\circ} \mathrm{N}, 5.7^{\circ} \mathrm{E} ; 420 \mathrm{~m}\right)$, is a mixed stand where $P i$ nus halepensis Mill. dominates the open-top canopy layer reaching about $12 \mathrm{~m}$; Quercus ilex L. forms a lower canopy 
layer, reaching about $6 \mathrm{~m}$, and there is a sparse shrub understory which includes Quercus coccifera L. (Simioni et al., 2013). The second site, Puechabon ( $\left.43.4^{\circ} \mathrm{N}, 3.4^{\circ} \mathrm{E} ; 270 \mathrm{~m}\right)$, is a dense coppice in which overstorey is dominated by $Q$. ilex with a density of around 6000 stems ha $^{-1}$ (Rambal et al., 2004; Limousin et al., 2012). Both forests grow on rocky and shallow soils that have a low retention capacity and are of Jurassic limestone origin. The climate is Mediterranean, with a water stress period in summer, cold or mild winters and most precipitation occurring between September and May. Meteorological data were obtained from the neighbouring stations of St. Martin de Londres (for Puechabon) and Aubagne (for Fontblanche). According to those data Puechabon is colder and receives more precipitation than Fontblanche (Table 1). Meteorological data showed a decrease in total rainfall since the 1970 s in Puechabon but no trend in Fontblanche. Both sites exhibit a positive trend in temperatures more evident for the maximum values (Fig. A1).

We assumed that GPP (gross primary productivity) is driven by the top pine and/or oak layers and that the percentage of LAI related to the understory shrub layer will behave like that of the oak species (evergreen, shrubby). For Fontblanche we considered a maximum leaf area index (LAI $\left.\mathrm{Lax}_{\text {max }}\right)$ of $2.2 \mathrm{~m}^{2} \mathrm{~m}^{-2}\left(3 \mathrm{~m}^{2} \mathrm{~m}^{-2}\right.$ plant area index, PAI), composed of $70 \%$ pine and $30 \%$ oak (Simioni et al., 2013). For Puechabon we considered an $\mathrm{LAI}_{\max }$ of $2.0 \mathrm{~m}^{2} \mathrm{~m}^{-2}$ (2.8 $\mathrm{m}^{2} \mathrm{~m}^{-2}$ PAI) monospecific to $Q$. ilex (Baldocchi et al., 2010; Limousin et al., 2012). The specific leaf area (SLA) considered was $0.0045 \mathrm{~m}^{2} \mathrm{~g}^{-1}$ for $Q$. ilex and $0.0037 \mathrm{~m}^{2} \mathrm{~g}^{-1}$ for P. halepensis (Hoff and Rambal, 2003; Maseyk et al., 2008).

\subsection{The model}

We used MAIDEN (Misson, 2004), a stand productivity mechanistic model driven by a number of functions and parameters representing different processes. The model inputs are precipitation, maximum and minimum temperature, and $\left[\mathrm{CO}_{2}\right]$ with a daily time step. This model has been previously implemented for monospecific forests, including two oaks and one pine species, using dendroecological chronologies of growth and, when available, stand transpiration estimates from sap-flow sensors (Misson et al., 2004; Gaucherel et al., 2008). However, the model has never been compared to actual $\mathrm{CO}_{2}$ flux data to ensure that it provides unbiased estimates of forest productivity. In this study, the model was further developed to match ground-based observations and generalize model use by modifying the photosynthesis and allocation modules (including the different phenophases) in relation to climatic drivers. To properly scale model outputs and get unbiased estimates of stand productivity, we used $\mathrm{CO}_{2}$ eddy covariance fluxes (Baldocchi, 2003). Different parameters were calibrated to different data sources, including some species-dependent and some site-dependent parameters, as follows. The transpiration rate $(E)$ of day $i$ is calculated us- ing a conductance approach: $E(i)=g_{\mathrm{s}}(i) \times \operatorname{VPD}(i) / P_{\mathrm{atm}}(i)$, where $P_{\mathrm{atm}}$ is atmospheric pressure and $g_{\mathrm{s}}$ and VPD are stomatal conductance and vapour pressure deficit, respectively, as described below (Misson, 2004). The other equations used to calculate micrometeorological covariates, soil humidity and photosynthetic active radiation, as well as those functions describing the water cycle (including soil evaporation and plant transpiration) are explained in the original model formulation by Misson (2004). Therefore, they will not be described here. The rest of the model was modified as follows.

\subsection{Modelling the effect of climatic forcing on photosynthesis}

Leaf photosynthesis $\left(A_{n}\right)$ is calculated based on the biochemical model of Farquhar et al. (1980). $A_{n}$ is a function of the carboxylation $\left(V_{\mathrm{c}}\right)$, oxygenation $\left(V_{\mathrm{o}}\right)$ and leaf dark respiration rates $\left(R_{\mathrm{d}}\right): A_{n}=V_{\mathrm{c}}-0.5 V_{\mathrm{o}}-R_{\mathrm{d}}$, where photosynthesis during the day $i$ is limited by either the rate of carboxylation when Rubisco is saturated $\left(W_{\mathrm{c}}\right)$ or when it is limited by electron transport $\left(W_{\mathrm{j}}\right)$, i.e. $A_{\mathrm{c}}=V_{\mathrm{c}}-0.5 V_{\mathrm{o}}=\min \left\{W_{\mathrm{c}}, W_{j}\right\}$. $R_{\mathrm{d}}$ was considered a fixed function of $A_{\mathrm{c}}\left(0.006 \times A_{\mathrm{c}}\right)$ because this formulation performed better than an exponential function of temperature (Sala and Tenhunen, 1996; De Pury and Farquhar, 1997; Bernacchi et al., 2001). Following De Pury and Farquhar (1997):

$$
\begin{aligned}
& W_{\mathrm{c}}(i)=\frac{V_{\mathrm{cmax}}(i) \cdot\left(C_{i}(i)-\Gamma(i)\right)}{C_{i}(i)+K_{\mathrm{c}}(i)\left(1+\frac{\left[\mathrm{O}_{2}\right]}{K_{\mathrm{o}}(i)}\right)}, \\
& W_{j}(i)=\frac{J_{\max }(i) \cdot\left(C_{i}(i)-\Gamma(i)\right)}{4 C_{i}(i)+8 \Gamma(i)},
\end{aligned}
$$

where $C_{i}$ is the $\mathrm{CO}_{2}$ intercellular concentration, $\Gamma$ is the $\left[\mathrm{CO}_{2}\right]$ compensation point for photosynthesis in the absence of dark respiration, and $K_{\mathrm{c}}$ and $K_{\mathrm{o}}$ are the kinetic MichaelisMenten constants for carboxylation and oxygenation, respectively. $V_{\mathrm{cmax}}$ and $J_{\max }$ are temperature-dependent parameters, as outlined below. Photosynthesis is known to respond to the carbon concentration within chloroplasts $C_{\mathrm{c}}$ rather than to $C_{\mathrm{i}}$. Throughout the paper we retain the notation presented here in Eqs. (1) and (2) but discuss below how mesophyll conductance is taken into account empirically in relation to water stress when calculating $g_{\text {s }}$ and acknowledge the possible limitations of our approach (Reichstein et al., 2002; Grassi and Magnani, 2005; Flexas et al., 2006; Sun et al., 2014).

Climate influences leaf photosynthesis calculations through the temperature dependence of different parameters (Bernacchi et al., 2001; Nobel, 2009). $\Gamma, K_{\mathrm{c}}$ and $K_{\mathrm{o}}$ were modelled using Arrhenius functions of daily mean temperature $\left(T_{\text {day }}\right.$, in $\left.{ }^{\circ} \mathrm{C}\right)$ with parameters from De Pury and Farquhar (1997). We modelled $J_{\max }$ as a fixed rate of $V_{\mathrm{cmax}}$ $\left(J_{\max }(i)=J_{\text {coef }} \cdot V_{\text {cmax }}(i)\right)$ after comparing it with different temperature-dependent formulations (De Pury and Farquhar, 
Table 1. Characteristics of mean annual gross primary productivity, climatic (annual means) and growth data. Standard deviations are shown in parentheses. Precipitation: mean annual precipitation; $T_{\max }$ : annual mean of mean daily maximum temperature; $T_{\min }$ : annual mean of mean daily minimum temperature; length: chronology year replicated with more than 5 radii; RW: mean annual ring width; Rbs: mean correlation between series; AR: mean autocorrelation of raw series; MS: mean sensitivity; EPS: mean expressed population signal. Rbs, AR, MS and EPS are classical statistics to characterize growth chronologies, and they follow Fritts (1976).

\begin{tabular}{|c|c|c|c|c|}
\hline & & \multicolumn{2}{|c|}{ Fontblanche } & Puechabon \\
\hline \multirow[t]{3}{*}{ Flux data } & Period & \multicolumn{2}{|c|}{ 2008-2012 } & 2001-2013 \\
\hline & GPP annual & \multirow{2}{*}{\multicolumn{2}{|c|}{$\begin{array}{l}1431.4 \\
(305.4)\end{array}$}} & 1207.3 \\
\hline & $\left(\mathrm{g} \mathrm{C} \mathrm{m}^{-2}\right.$ year $\left.^{-1}\right)$ & & & (206.7) \\
\hline \multirow[t]{4}{*}{ Climate } & Period & \multicolumn{2}{|c|}{ 1964-2012 } & 1954-2013 \\
\hline & Precipitation (mm) & \multicolumn{2}{|c|}{$642.7(169.7)$} & $1002.6(328.2)$ \\
\hline & $T_{\max }\left({ }^{\circ} \mathrm{C}\right)$ & \multicolumn{2}{|c|}{$20.6(0.9)$} & $17.8(1.26)$ \\
\hline & $T_{\min }\left({ }^{\circ} \mathrm{C}\right)$ & \multicolumn{2}{|c|}{$8.8(0.5)$} & $8.1(0.8)$ \\
\hline \multirow[t]{8}{*}{ Growth data } & Species & P. halepensis & Q. ilex & Q.ilex \\
\hline & No. of trees/radii & $25 / 47$ & $15 / 30$ & $17 / 32$ \\
\hline & Length & 1910-2013 & 1941-2013 & $1941-2005$ \\
\hline & RW (mm) & $2.19(1.1)$ & $1.25(0.7)$ & $1.13(0.7)$ \\
\hline & MS & 0.308 & 0.372 & 0.443 \\
\hline & AR & 0.684 & 0.591 & 0.436 \\
\hline & Rbs & 0.541 & 0.281 & 0.457 \\
\hline & EPS & 0.963 & 0.884 & 0.949 \\
\hline
\end{tabular}

1997; Maseyk et al., 2008). The model behaviour was better when the temperature dependence of $V_{\text {cmax }}$ was modelled using a logistic function (Gea-Izquierdo et al., 2010) rather than an exponential function as in Misson (2004):

$V_{\mathrm{cmax}}(i)=\frac{V_{\max }}{\left(1+\exp \left(V_{b} \cdot\left(\left(T_{\text {day }}(i)+273\right)-V_{\mathrm{ip}}\right)\right)\right)} \cdot \theta_{\mathrm{p}}$

$V_{\max }, V_{b}$ and $V_{\text {ip }}$ are parameters to be estimated, with $V_{\max }$ being the asymptote and $V_{\mathrm{ip}}$ the inflection point. $\theta_{\mathrm{p}}$ is a soil water stress function dependent on the soil moisture conditions of the previous year. It takes into account the downregulation of photosynthesis in response to protracted drought through its impact on the photosynthetic capacity of active LAI in evergreen species caused by constraints in $V_{\text {cmax }}$, in turn produced by irreversible photoinhibition, modifications in leaf stoichiometry and/or the aging of standing foliage through lower leaf replacement rates in response to long-term water stress (Sala and Tenhunen, 1996; Niinemets and Valladares, 2004; Niinemets, 2007; Vaz et al., 2010).

$\theta_{\mathrm{p}}=1-\exp \left(p_{\mathrm{str}} \cdot \mathrm{SWC}_{180}\right)$

where $p_{\text {str }}$ is a parameter to be estimated and $\mathrm{SWC}_{180}$ is the mean soil water content ( $\mathrm{mm}$ ) from July to December of the previous year.

Photosynthesis is coupled to the calculation of stomatal conductance, which is estimated using a modified version of the Leuning (1995) equation:

$g_{\mathrm{s}}(i)=\frac{g_{1} \cdot A_{n}(i)}{\left(C_{\mathrm{s}}(i)-\Gamma(i)\right) \cdot\left(1+\mathrm{VPD}(i) / \mathrm{VPD}_{0}\right)} \cdot \theta_{\mathrm{g}}(i)$, where $\mathrm{g}_{1}$ and $\mathrm{VPD}_{0}$ are parameters; $\operatorname{VPD}(i)$ is daily vapour pressure deficit; $C_{\mathrm{s}}$ is the leaf surface $\left[\mathrm{CO}_{2}\right] ; \theta_{\mathrm{g}}$ is a nonlinear soil water stress function calculated as

$\theta_{\mathrm{g}}(i)=\frac{1}{1+\exp \left(\operatorname{soil}_{b} \cdot\left(\operatorname{SWC}(i)-\operatorname{soil}_{\mathrm{ip}}\right)\right)}$

soil $_{b}$ and soil $_{\mathrm{ip}}$ are parameters; and $\mathrm{SWC}(i)$ is daily soil water content $(\mathrm{mm}) . \theta_{\mathrm{g}}$ accounts for variability in gas exchange under drought conditions which cannot be taken into account through stomatal control alone; thus, the variability can also be related to, e.g., mesophyll conductance or stomatal patchiness. Therefore, with this empirical expression, we partly represent the effect of $\mathrm{CO}_{2}$ fractionation during mesophyll conductance under water stress, acknowledging that this will likely be more complex under environmental stress (Reichstein et al., 2002; Grassi and Magnani, 2005; Flexas et al., 2006; Sun et al., 2014). The coupled photosynthesis-stomatal conductance system of equations was estimated separately for sun and shade leaves. Canopy photosynthesis was integrated using LAI, divided into its sunlit and shaded fractions (De Pury and Farquhar 1997). Transmission and absorption of irradiance was calculated following the Beer-Lambert law as a function of LAI, with $\mathrm{LAI}_{\text {sun }}=(1-\exp (-\mathrm{LAI})) \cdot K_{\mathrm{b}}$ ( $K_{\mathrm{b}}$ is the beam light extinction coefficient, which was set to 0.8) and $\mathrm{LAI}_{\text {shade }}=\mathrm{LAI}-\mathrm{LAI}_{\text {sun }}$ (Misson, 2004). In the mixed stand (Fontblanche), photosynthesis was calculated separately for $Q$. ilex and $P$. halepensis and then integrated to obtain stand estimates of forest productivity. 


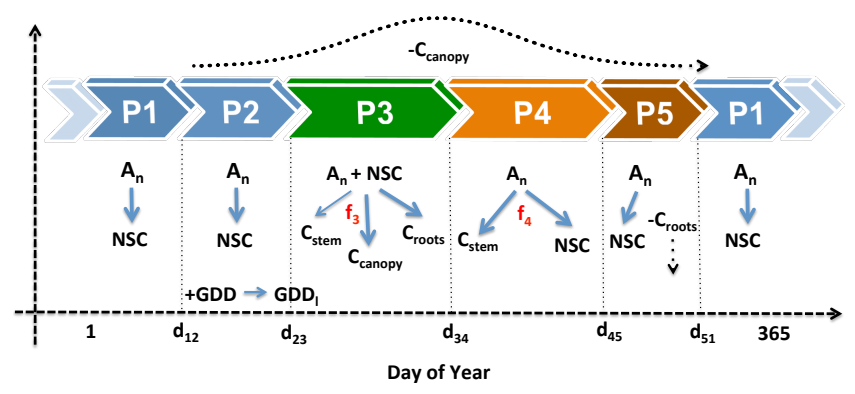

Figure 1. Outline of the different phenological phases (P1 to P5) and carbon allocation in the model within a given year. $A_{\mathrm{n}}$ : net daily carbon assimilation; NSC: storage (non-structural carbohydrates); GDD: growing degree days; $\mathrm{GDD}_{1}=$ parameter determining shift from P2 to P3 (see text); C: carbon allocated either to the stem, canopy or roots; $d$ : day of year. Solid arrows correspond to allocation within the plant, whereas dashed arrows correspond to litterfall (canopy or roots). $f_{3}$ and $f_{4}$ are nonlinear functions of soil water content and temperature, determining carbon allocation to different compartments (see text for more details).

\subsection{Modelling the effect of climatic forcing on carbon allocation}

The model allocates daily carbon assimilated either to the canopy, stem, roots or storage of non-structural carbohydrates (NSC) to mimic intra-annual carbohydrate dynamics (Misson, 2004; Dickman et al., 2015). Although trees can store carbon within different above-ground and belowground compartments (Millard et al., 2007), carbon storage is treated as a single pool within the model. Tree autotrophic respiration $\left(R_{\mathrm{a}}\right.$, in addition to $\left.R_{\mathrm{d}}\right)$ is modelled as a function $f(i)$ of daily photosynthesis and maximum daily temperature ( $T_{\max }$; Sala and Tenhunen, 1996; Nobel, 2009):

$R_{a}(i)=A_{n}(i) \cdot \max \{0.3, f(i)\}$, with $f(i)=0.47$

$\cdot\left(1-\exp \left(p_{\text {respi }} \cdot T_{\max }(i)\right)\right.$,

where $p_{\text {respi }}$ is a parameter. Net photosynthesis is calculated for day $i$ as $A_{\mathrm{N}}(i)=A_{n}(i)-R_{a}(i)$. This assumption means that respiration would be considered zero when there is no photosynthesis; hence, maintenance respiration would not be taken into account those days. Although this could bias the overall carbon balance, we assume that this effect will be very reduced in the studied forests because they present photosynthetic activity all year round (see results). The model simulates several phenological phases during the year (see Fig. 1):

(P1) winter period where all photosynthates assimilated daily, $A_{\mathrm{N}}(i)$, are allocated to the storage reservoir (NSCs) but there is no accumulation of growing degree days (GDD).

(P2) winter period where all $A_{\mathrm{N}}(i)$ are allocated to storage (i.e. the same as in (P1)), but in contrast to (P1) there is active accumulation of GDD, which defines the threshold $\mathrm{GDD}_{1}$ to trigger the next phenophase (P3) (budburst, leaf flush).

(P3) budburst, where carbon-available $C_{\mathrm{T}}(i)=A_{\mathrm{N}}(i)+C_{\mathrm{bud}}$ ( $C_{\text {bud }}$ is daily $\mathrm{C}$ storage utilized from buds, a parameter) is either allocated to the canopy, to roots or to the stem.

(P4) once the canopy has been completed in (P3), the next phenophase (P4) starts; in this period, daily photosynthates $A_{\mathrm{N}}(i)$ are allocated either to the stem or to storage;

(P5) the last phenophase (P5) starts when the photoperiod (parameter) crosses a minimum threshold in fall. In this phase, root mortality occurs. Otherwise (P5) is similar to (P1) and (P2) in the sense that all $A_{\mathrm{N}}(i)$ is used for storage until next year's (P3) starts.

The allocation of carbon to different plant compartments is complex because it can be decoupled from photosynthetic production depending on different factors, some of them climatic, acting on different temporal scales (Friedlingstein et al., 1999; Sala et al., 2012; Chen et al., 2013; McMurtrie and Dewar, 2013). In this new version of the model, we set the different allocation relationships as nonlinear functions of temperature and soil water content, $h(i)=f_{1}\left(T_{\max }\right)$. $f_{2}$ (SWC), in (P3) and (P4) following the functional relationships described in Gea-Izquierdo et al. (2013). This means that now we take into account homeostatic acclimation processes at the canopy level related to LAI dependence on water availability (Hoff and Rambal, 2003; Sala and Tenhunen, 1996; Reichstein et al., 2003). LAI is negatively related to long-term drought because litterfall is negatively linked to water stress (Limousin et al., 2009; Misson et al., 2011) and bud size depends on the climate influencing the period of bud formation (Montserrat-Marti et al., 2009). Therefore, the actual carbon that can be allocated to the canopy in (P3) of year $j$ (AlloC $_{\text {canopy }}(j)$ ) was set as a function of the previous year's moisture conditions $\left(\theta_{\mathrm{LAI}}(j)\right)$ and the maximum carbon that can be allocated to the canopy $\left(\mathrm{MaxC}_{\text {canopy }}\right) . \mathrm{MaxC}_{\text {canopy }}$ is calculated from $\mathrm{LAI}_{\max }$ and SLA, and $\operatorname{AlloC}_{\text {canopy }}(j)=\theta_{\text {LAI }}(j) \times \operatorname{MaxC}_{\text {canopy }}$, where

$\theta_{\mathrm{LAI}}(j)=\left(1-2 \cdot \frac{p_{\mathrm{LAI}}-\mathrm{SWC}_{250}}{p_{\mathrm{LAI}}}\right)$,

constrained to $\theta_{\mathrm{LAI}}(j) \in[0.7,1.0]$.

$p_{\text {LAI }}$ is a parameter to be calibrated representing the threshold over which $\theta_{\mathrm{LAI}}(j)=1$ and $\mathrm{SWC}_{250}$ is mean soil water content for May-December of the previous year.

Leaf turnover is variable within years and partly related to water availability (Limousin et al., 2009, 2012). We considered a mean leaf turnover rate of 3 years for pines and 2 for oaks. To model within-year variability in leaf phenology (i.e. leaf growth and litterfall), we followed Maseyk 
et al. (2008) and Limousin et al. (2009; Fig. 1). C allocation to the canopy (i.e. including primary growth) in (P3) is calculated as $C_{\text {canopy }}(i)=C_{T}(i) \times\left(1-0.2 \times h_{3 \_1}(i)\right) \times$ Ratio $_{\text {root/leaf }}^{-1}$; Ratioroot/leaf was fixed to 1.5 for both species (Misson et al., 2004; Ourcival, unpublished data), and

$$
\begin{aligned}
& h_{3 \_1}(i)=\left(1-\exp \left(p_{3 \text { moist }} \cdot \operatorname{SWC}(i)\right)\right) \\
& \left(\exp \left(-0.5 \cdot\left(\frac{T_{\max }(i)-p_{3 \mathrm{temp}}}{p_{3 \mathrm{sd}}}\right)^{2}\right)\right)
\end{aligned}
$$

where $p_{3 \text { moist }}, p_{3 \text { temp }}$ and $p_{3 \text { sd }}$ are parameters representing the scale of the SWC and the optimum and dispersion of the $T_{\max }$ functions, respectively. The carbon allocated to the stem $\left(C_{\text {stem }}\right)$ in $(\mathrm{P} 3)$ is $C_{\text {stem }}(i)=C_{T}(i) \times 0.2 \times h_{3 \_}(i) \times h_{3 \_}(i)$, where

$$
\begin{aligned}
& h_{3 \_2}(i)=\left(1-\exp \left(\mathrm{st}_{3 \text { moist }} \cdot \operatorname{SWC}(i)\right)\right) \\
& \cdot\left(\exp \left(-0.5 \cdot\left(\frac{T_{\max }(i)-\mathrm{st}_{3 \mathrm{temp}}}{\mathrm{st}_{3 \mathrm{sd} \_t \mathrm{temp}}}\right)^{2}\right)\right)
\end{aligned}
$$

with $h_{3 \_1}(i)$ as in Eq. (9); st 3 moist, $\mathrm{st}_{3 \text { temp }}$ and $\mathrm{st}_{3 \mathrm{sd} \text { temp }}$ are parameters as in $h_{31}(i)$. The carbon allocated to roots in (P3) is set complementary to that of the other compartments to close the carbon budget within the tree, i.e. $C_{\text {roots }}(i)=$ $C_{T}(i)-C_{\text {stem }}(i)-C_{\text {canopy }}(i)$.

Finally, in (P4) carbon-assimilated daily $A_{\mathrm{N}}(i)$ is allocated either to stem growth or to storage until changing to (P5). In (P4), the amount of carbon to be allocated to stem growth is also set as a function of climatic forcing:

$C_{\text {stem }}(i)=A_{\mathrm{N}}(i) \times\left(1-h_{4}(i)\right)$ and $C_{\text {stor }}(i)=A_{\mathrm{N}}(i) \times$ $h_{4}(i)$, with

$$
\begin{aligned}
& h_{4}(i)=\left(1-\exp \left(\mathrm{st}_{4 \mathrm{temp}} \cdot T_{\max }(i)\right)\right) \\
& \cdot\left(\exp \left(-0.5 \cdot\left(\frac{\mathrm{SWC}(i)}{\mathrm{st}_{4 \mathrm{sd} \_ \text {moist }}}\right)^{2}\right)\right)
\end{aligned}
$$

where $s_{4 t e m p}$ and $s_{4 s d \_t e m p}$ are parameters.

\subsection{Eddy covariance $\mathrm{CO}_{2}$ flux and dendrochronological data}

The process-based model was calibrated using daily gross primary productivity (GPP), dendrochronological data and inventory data. To develop the model, those functions used to model daily stand photosynthesis (i.e. Eq. 1 to 9) were first calibrated against GPP values. GPP estimates were obtained from half-hourly net $\mathrm{CO}_{2}$ flux measurements (NEP). GPP was obtained as the difference between measured net ecosystem productivity and calculated ecosystem respiration (Reichstein et al., 2005). Negative GPP values were corrected following Schaefer et al. (2012). Half-hourly GPP data were integrated to obtain daily estimates for the period 2001-2013 (Puechabon, methods detailed in Allard et al., 2008) and 2008-2012 (Fontblanche, Table 1).

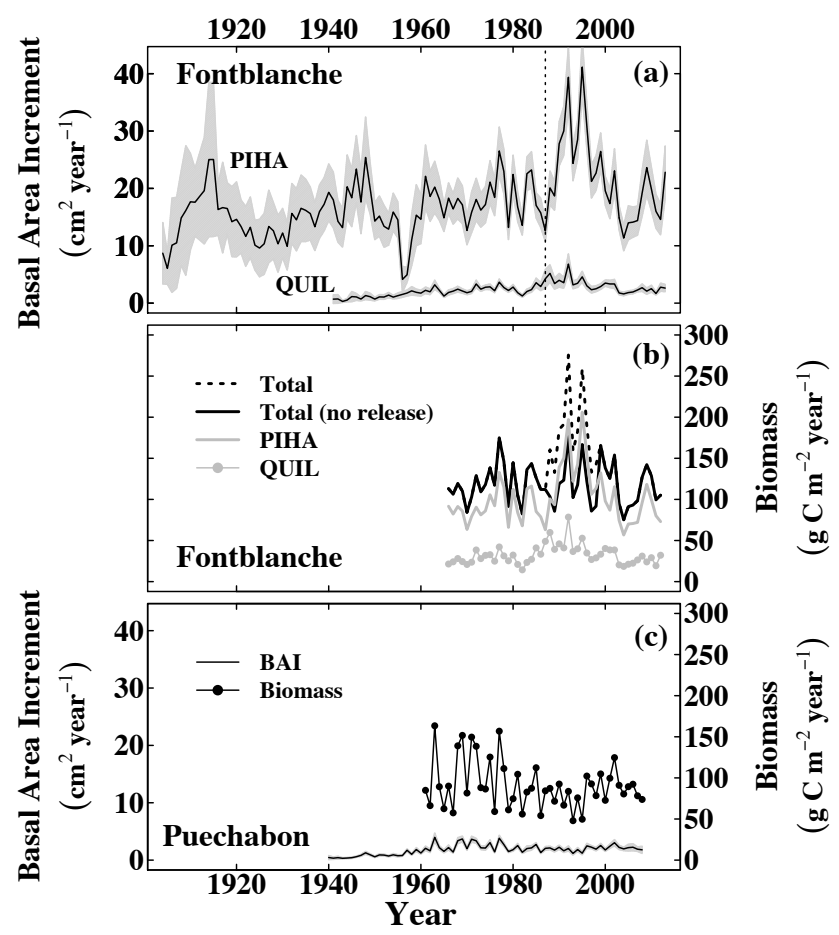

Figure 2. Growth (basal area increment, BAI, $\mathrm{cm}^{2} \mathrm{yr}^{-1}$ ) and biomass allocated to the tree stem $\left(\mathrm{g} \mathrm{C} \mathrm{m}^{-2} \mathrm{yr}^{-1}\right)$ of $Q$. ilex and $P$. halepensis at Fontblanche (growth shown in a, biomass in $\mathbf{b}$ ) and $Q$. ilex at Puechabon (growth and stem biomass shown in c). A vertical dashed line marks the release event in Fontblanche produced by the enhanced winter mortality in 1985 in (a). Dark lines for BAI correspond to yearly means while grey polygons show confidence intervals (at $95 \%$ ) on the standard errors of the mean.

In the second step, those functions used to model how carbon assimilated and/or storage is allocated to the growth of the tree stem (i.e. Eqs. 10 and 11) were developed using calculated annual stem biomass increment time series. Stem biomass increment chronologies were built combining dendroecological data and forest inventory data collected at each site. We built one chronology for $Q$. ilex in Puechabon, a second for $Q$. ilex in Fontblanche and a third one for $P$. halepensis at Fontblanche (Fig. 2). For pines, two perpendicular cores were extracted using an increment borer from 25 trees in fall 2013, whereas for oaks we used cross sections. In Fontblanche, 15 oak stems were felled and basal sections collected in spring 2014. A total of 17 oak stems from Puechabon were logged in 2005 and 2008. The age and diameter distributions of the studied forests are depicted in Fig. A2.

All samples were processed using standard dendrochronological methods (Fritts, 1976). Annual growth (RW) was measured using a stereomicroscope and a moving table connected to a computer. RW cross-dating was visually and statistically verified. RW estimates were transformed to basal area increments (BAI, $\mathrm{cm}^{2} \mathrm{yr}^{-1}$ ). Mean BAI chronologies were obtained by averaging individual tree BAI time series. 
In Fontblanche, BAI during the period 1987-1995 was standardized relative to the mean calculated after excluding that period (Fig. 2). BAI data were standardized because we did not find a climatic explanation for the abrupt growth peak observed in Fontblanche during that period (Fig. 2). Therefore, we assumed that it had been caused by a release event (i.e. reduction in competition) produced by the death of neighbours as a consequence of winter frost during 1985 and 1987 (Vennetier, personal communication, 2014). These two frosts were reflected by the presence of characteristic frost rings in most individuals from Fontblanche.

To scale BAI chronologies to the same units as annual stem biomass (which is an output of the model), we used plot inventory data collected around the flux towers at the two sites. Inventory data included stem diameter for all trees and tree height collected for a subsample every 2 years during 20072011 in Fontblanche as well as annual diameter estimates for the period 1986-2011 for Puechabon. Individual annual biomass increments were estimated by subtracting the stem biomass of one year from that of the next; then, stand stem biomass increments (SBIs, $\mathrm{g} \mathrm{C} \mathrm{m}^{-2} \mathrm{yr}^{-1}$ ) were calculated by integrating plot data. Stem biomass was calculated using allometric functions. For pines, we calculated stem biomass using diameter and estimated stem height assuming that the tree bole follows a paraboloid shape (Li et al., 2014). For oaks, stem biomass was calculated following Rambal et al. (2004). Once SBI had been estimated for the years when we had available inventory data, BAI chronologies were correlatively scaled to SBI units $\left(\mathrm{g} \mathrm{C} \mathrm{m}^{-2} \mathrm{yr}^{-1}\right)$. We built two mean stand SBI chronologies, one for each site, meaning that we analysed carbon allocation within stands, not differentiating between species in Fontblanche. These two SBI chronologies were used to calibrate sitewise Eqs. (10) and (11).

\subsection{Model development and analyses}

Parameters were selected according to the ecological characteristics of the species, exploring the model using comprehensive sensitivity analysis to sequentially optimize groups of parameters. In a first step, a group of common parameters was selected using GPP data from Fontblanche (Table 2). The species-dependent parameters selected for $Q$. ilex in this first step (those parameters in Table 2 which are common to the two sites) were independently validated when applied in Puechabon. In a second step, a subset of site-dependent parameters was calibrated against GPP and SBI data. Four parameters from Eqs. (6) and (9) were calibrated using GPP data, and five parameters in Eqs. (10) and (11) were calibrated using stem biomass increment data (Table 2). The local parameters were calibrated constrained to an ecologically realistic range and using a global optimization algorithm and maximum likelihood principles (Gaucherel et al., 2008).

To compare model output with stem biomass chronologies as estimated from dendroecological data, we used only the period for which we had available daily meteorological data (1960-2013), which was also a period that did not include juvenile years with increasing BAI (BAIs reached an asymptote after increasing for the first 15-20 juvenile years; Fig. 2). The model does not take into account how size differences in allometry or ontogeny affect carbon allocation (Chen et al., 2013). We tried to keep the model as simple as possible also because we had no such data to calibrate ontogenic effects. Hence, the model is designed for non-juvenile stands with canopies that reached a steady state with asymptotic $\mathrm{LAI}_{\max }$. For the same reasons it does not take into account how changes in management affect carbon allocation. The model was analysed in terms of goodness of fit. Additionally, for the period for which we had available daily meteorological data, we simulated time series of GPP, ecosystem water use efficiency (WUE $=$ GPP/ET, with ET being actual evapotranspiration) and intrinsic water use efficiency of sun leaves (iWUE $=A_{\mathrm{N}} / g_{\mathrm{s}}$ ) calculated following Beer et al. (2009).

\section{Results}

The studied evergreen forests exhibit a bimodal pattern in GPP with maxima in spring and autumn (Fig. 3) as often observed in Mediterranean ecosystems (e.g. Baldocchi et al., 2010). GPP was above 0 almost every day of the year, including in winter, particularly at the milder site, Fontblanche (Table 1). This means that there is active photosynthesis all year round in these evergreen forests, including during both periods of climatic stress, i.e. those with low temperature and short photoperiod in winter and with low moisture availability in summer (Fig. 3). Mean annual GPP was $1431.4 \pm 305.4 \mathrm{~g} \mathrm{C} \mathrm{m}^{-2} \mathrm{yr}^{-1}$ and precipitation $642.7 \pm 169.7 \mathrm{~mm}$ in Fontblanche, whereas it was $1207.3 \pm 206.7 \mathrm{~g} \mathrm{C} \mathrm{m}^{-2} \mathrm{yr}^{-1}$ and $1002.6 \pm 328.2 \mathrm{~mm}$ in Puechabon (see Table 1 for more details). Mean GPP was higher at Fontblanche because carbon assimilation was greater in the low-temperature winter period but similar the rest of the year (Fig. 3). Stem growth did not show any longterm (decadal) growth trend for any of the species studied (Fig. 2).

The model accurately represented the low-frequency response of daily GPP: both the seasonal variability in GPP within years and variability in GPP among years (Fig. 4). The model explained over $50 \%$ of the annual biomass growth variance, and 46 and $59 \%$ of daily GPP in Fontblanche and Puechabon, respectively (Fig. 4). This means that we were able to mimic the daily, seasonal and long-term trends in stand productivity with unbiased estimates but also to model how carbon is allocated to stem growth throughout the year during the different phenophases described. The model assumed species-specific carbon allocation responses set to the different plant compartments as nonlinear functions of temperature and soil moisture. These relationships were biologically meaningful in the sense that photosynthesis and carbon 
Table 2. Model parameters. Those parameter differing between sites were optimized either with GPP data (photosynthesis and allocation module) or with growth-based biomass increment chronologies (allocation module). The rest were common parameters for both sites and selected while developing the model in the first step for Fontblanche using GPP data (represented in the "Cal" column by "-"). Meaning of parameters, equation number (E) and phenophase (P) are as in the Material and Methods section. Fontb: Fontblanche; Puech: Puechabon; Cal: local parameters to be calibrated with GPP or stem biomass increment data (SBI); PIHA: Pinus halepensis; QUIL: Quercus ilex.

\begin{tabular}{|c|c|c|c|c|c|c|c|}
\hline \multirow{3}{*}{$\begin{array}{l}\text { Process } \\
\text { Photosynthesis }\end{array}$} & \multirow{3}{*}{$\begin{array}{l}\text { Process/equation no. } \\
\text { Leaf photosynthesis (E2) }\end{array}$} & \multicolumn{2}{|c|}{ Parameter } & Fontb & Puech & \multirow{2}{*}{ 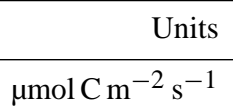 } & \multirow{2}{*}{$\begin{array}{r}\mathrm{Cal} \\
-\end{array}$} \\
\hline & & $J_{\text {coef }}$ & QUIL & \multicolumn{2}{|c|}{1.59} & & \\
\hline & & & PIHA & \multirow{2}{*}{\multicolumn{2}{|c|}{1.44}} & & \\
\hline & \multirow[t]{6}{*}{ Leaf photosynthesis (E3) } & \multirow[t]{2}{*}{$V_{\max }$} & QUIL & & & $\mu \mathrm{mol} \mathrm{C} \mathrm{m}{ }^{-2} \mathrm{~s}^{-1}$ & - \\
\hline & & & PIHA & 46.0 & - & & \\
\hline & & \multirow[t]{2}{*}{$V_{\mathrm{b}}$} & QUIL & \multicolumn{2}{|c|}{-0.106} & ${ }^{\circ} \mathrm{C}^{-1}$ & - \\
\hline & & & PIHA & -0.180 & - & & \\
\hline & & \multirow{2}{*}{$V_{\text {ip }}$} & QUIL & \multicolumn{2}{|c|}{13.7} & ${ }^{\circ} \mathrm{C}$ & - \\
\hline & & & PIHA & \multicolumn{2}{|c|}{20.0} & & \\
\hline & Stress $V_{\text {cmax }}(\mathrm{E} 4)$ & \multicolumn{2}{|c|}{$p_{\text {str }}$} & \multicolumn{2}{|c|}{-0.05} & $\mathrm{~mm}^{-1}$ & - \\
\hline & \multirow[t]{3}{*}{ Stomatal conductance (E5) } & \multirow[t]{2}{*}{$g_{1}$} & QUIL & \multicolumn{2}{|c|}{7.5} & - & - \\
\hline & & & PIHA & 6.1 & - & & \\
\hline & & \multicolumn{2}{|c|}{$\mathrm{VPD}_{0}$} & \multicolumn{2}{|c|}{30000} & $\mathrm{~Pa}$ & - \\
\hline & \multirow[t]{2}{*}{ Water stress (E6) } & \multirow{2}{*}{\multicolumn{2}{|c|}{$\begin{array}{l}\text { Soil }_{b} \\
\text { Soil }_{\text {ip }}\end{array}$}} & \multicolumn{2}{|c|}{-0.054} & $\mathrm{~mm}^{-1}$ & - \\
\hline & & & & 22.2 & 81.8 & $\mathrm{~mm}$ & GPP \\
\hline \multirow[t]{13}{*}{ Allocation } & Respiration (E7) & \multicolumn{2}{|c|}{$p_{\text {respi }}$} & \multicolumn{2}{|c|}{-0.225} & ${ }^{\circ} \mathrm{C}^{-1}$ & - \\
\hline & Stress LAI (E8) & \multirow{2}{*}{\multicolumn{2}{|c|}{$\begin{array}{c}p_{\text {LAI }} \\
\mathrm{GDD}_{1}\end{array}$}} & 65 & & $\mathrm{~mm}$ & - \\
\hline & $(\mathrm{P} 2)$ & & & 20 & & ${ }^{\circ} \mathrm{C}$ & - \\
\hline & Stored carbon buds (P3) & & & & & $\mathrm{gC} \mathrm{day}^{-1}$ & - \\
\hline & (P5) & Photc & eriod & & & hours & - \\
\hline & Allocation canopy (P3), (E9) & $\mathrm{st}_{4}$ & loist & -0.089 & -0.173 & $\mathrm{~mm}^{-1}$ & GPP \\
\hline & & $\mathrm{st}_{4}$ & $\mathrm{mp}$ & 53.3 & 75 & ${ }^{\circ} \mathrm{C}$ & GPP \\
\hline & & & & 26.9 & 26.1 & ${ }^{\circ} \mathrm{C}$ & GPP \\
\hline & Allocation stem (P3), (E10) & $\mathrm{st}_{3}$ & oist & -0.045 & -0.117 & $\mathrm{~mm}^{-1}$ & SBI \\
\hline & & & $\mathrm{mp}$ & 32.9 & 6.3 & ${ }^{\circ} \mathrm{C}$ & SBI \\
\hline & & & & 38.0 & 3.0 & ${ }^{\circ} \mathrm{C}$ & SBI \\
\hline & Allocation stor/stem (P4), (E11) & $\mathrm{st}_{4}$ & oist & 200.8 & 119.3 & $\mathrm{~mm}$ & SBI \\
\hline & & & $\mathrm{mp}$ & 0.060 & -0.097 & ${ }^{\circ} \mathrm{C}^{-1}$ & SBI \\
\hline
\end{tabular}

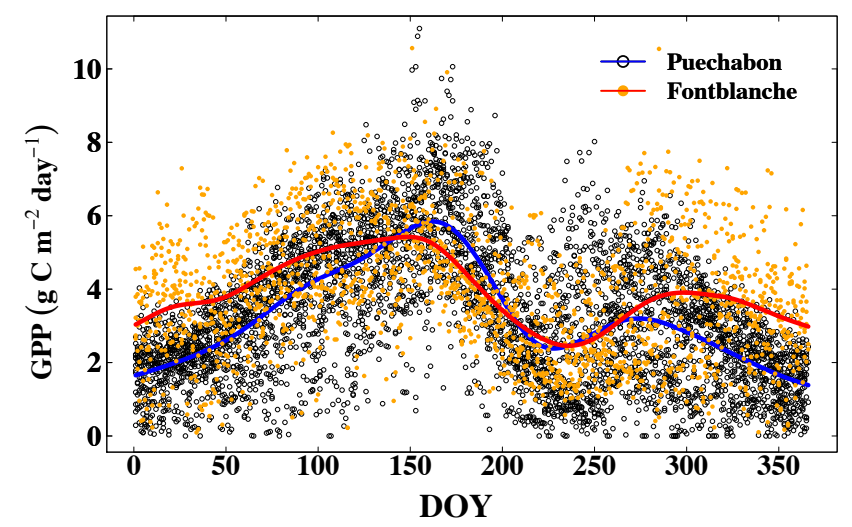

Figure 3. Daily gross primary productivity (GPP) at Puechabon (2001-2013, black dots, blue line) and Fontblanche (2008-2012, orange dots, red line). DOY: day of year. Thick lines correspond to smoothers fitted to the mean to highlight seasonal trends at the two sites. allocation could be decoupled to some extent as a function of climatic variability. Once the canopy had been formed in spring, the model allocated more carbon to the stem and less to storage when less severe climatic stress occurs, i.e. with decreasing temperatures and more humid conditions (Fig. 5).

Both sites exhibited an increase in temperature particularly evident in the maximum values, but only Puechabon suffered a decrease in annual precipitation between 1960 and 2012 (Fig. A1). In the model, the studied forests acclimated to changing conditions in the last decades, coupling different physiological traits, and simulated annual GPP largely followed the overall trends in precipitation observed. In Fontblanche, which is milder and receives less precipitation, GPP has remained stable since the 1960s and presented no apparent long-term trend (Fig. 6). In contrast, at the coldest and rainiest site (Puechabon), the model simulated a decrease in GPP (Fig. 6), which was driven by the prevailing decrease in precipitation observed since the 1970s (Figs. A1; 6 ). This reduction in GPP was partly a consequence of decreased LAI in response to enhanced long-term water stress 


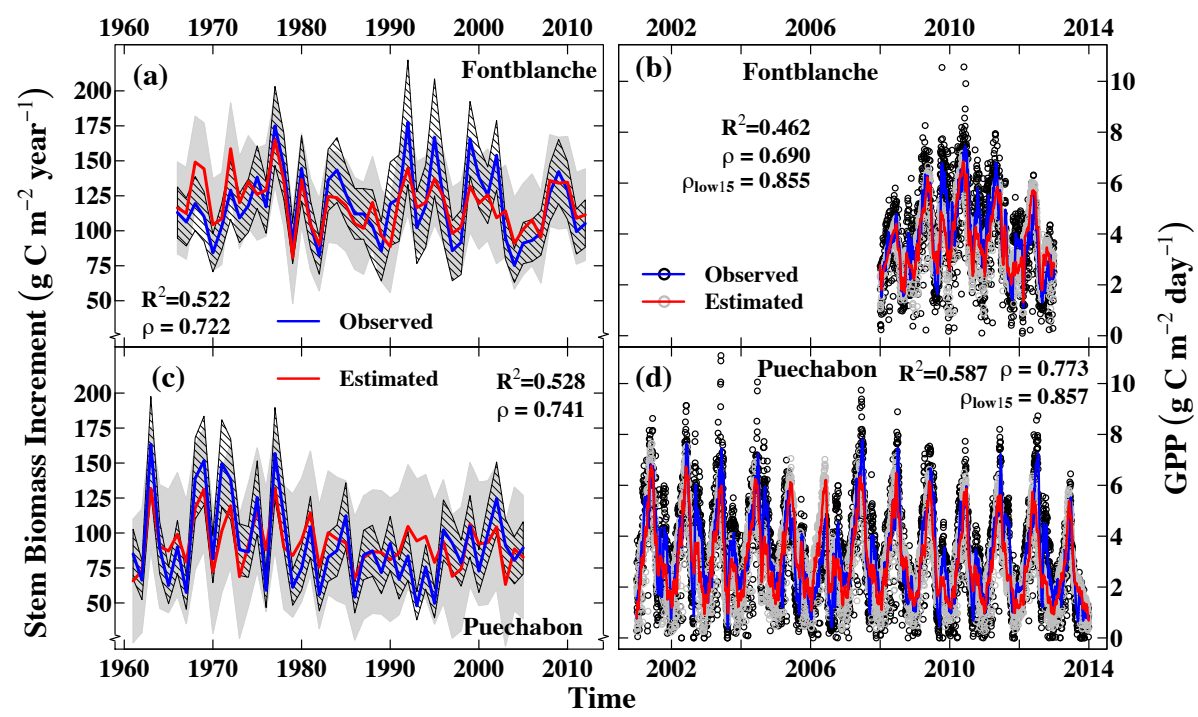

Figure 4. Model fit to stem biomass increment (a) and GPP (b) in Fontblanche and stem biomass increment (c) and GPP (d) in Puechabon. $R^{2}$ : coefficient of determination; $\rho$ : linear correlation between estimated and observed data; $\rho_{\text {low } 15}$ : linear correlation between estimated and observed data smoothed with a 15-year low-pass filter (blue and red lines in $\mathbf{b}$ and $\mathbf{c}$ ). Polygons behind the estimated values in (a) and (c) correspond to confidence intervals of the mean: solid grey polygons for estimated values and dashed polygons for observed stem biomass increment values.

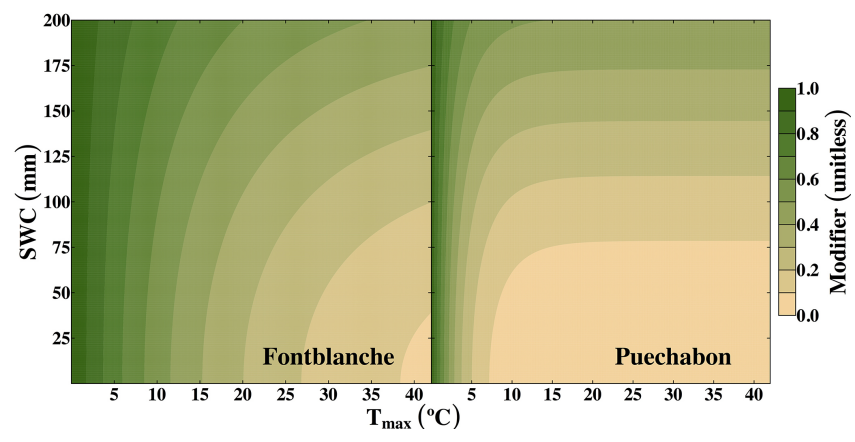

Figure 5. Modelled carbon allocation trajectory to the stem when leaf flush has finished in phenological period $(\mathrm{P} 4)$. We show the unitless modifier $1-h_{4}(i)$ (i.e. $h_{4}(i)$ is the portion of carbon allocated to storage) from $C_{\text {stem }}(i)=A_{\mathrm{N}}(i) \times\left[\left(1-h_{4}(i)\right)\right]$ in Eq. (11). The modifier $[0,1]$ is a function of soil water content (SWC) and maximum temperature (Tmax); multiplied with available daily carbon, it gives the distribution of daily carbon allocated to secondary growth and storage.

(Fig. A3; Limousin et al., 2009; Misson et al., 2011). Simulated long-term decadal trends in mean annual stomatal conductance were similar and decreased at the two sites with greater water stress as a consequence of enhanced temperatures (Fig. 6). The two species studied showed a long-term increase in simulated iWUE (Fig. 7) following the decrease in simulated $g_{\mathrm{s}}$ (Fig. 6). The interannual variability in WUE and iWUE were highly and positively correlated (Fig. 7). However, in the long-term they followed a different pattern, particularly in Puechabon, where there was a recent decline in WUE (not observed in iWUE) forced by trends in ET and GPP (Fig. 7). This means that the recent reduction in simulated GPP was proportionally greater than that of simulated ET (Figs. 6; A3).

\section{Discussion}

\subsection{Linking photosynthetic production to carbon allocation as a function of climate}

The model calculates stand productivity and carbon allocation to stem growth in response to climate and $\left[\mathrm{CO}_{2}\right]$ with realism. It is particularly well suited to mimic the effect of water stress in plant performance by the explicit assessment of different acclimation processes at the canopy level, including changes in stomatal conductance and photosynthetic capacity (Sala and Tenhunen 1996; Reichstein et al., 2003; Limousin et al., 2010; Misson et al., 2011). Additionally, the model simulates carbohydrate storage dynamically as a function of environmental variability. Climate can affect differently the carbon dynamics and pattern of $\mathrm{C}$ allocation to different tree compartments at different phenophases. In the model the storage reservoir is an active sink for assimilated carbon during some periods of the year and a source in spring to be used in primary and secondary growth (Fig. A5). Additionally stem growth is limited by climatic constraints (in (P3) and (P4)) rather than just by the amount of available carbohydrates (Millard et al., 2007). This means that water stress and optimum temperature directly affect the modelled processes, assuming that cell-wall expansion in the xylem 


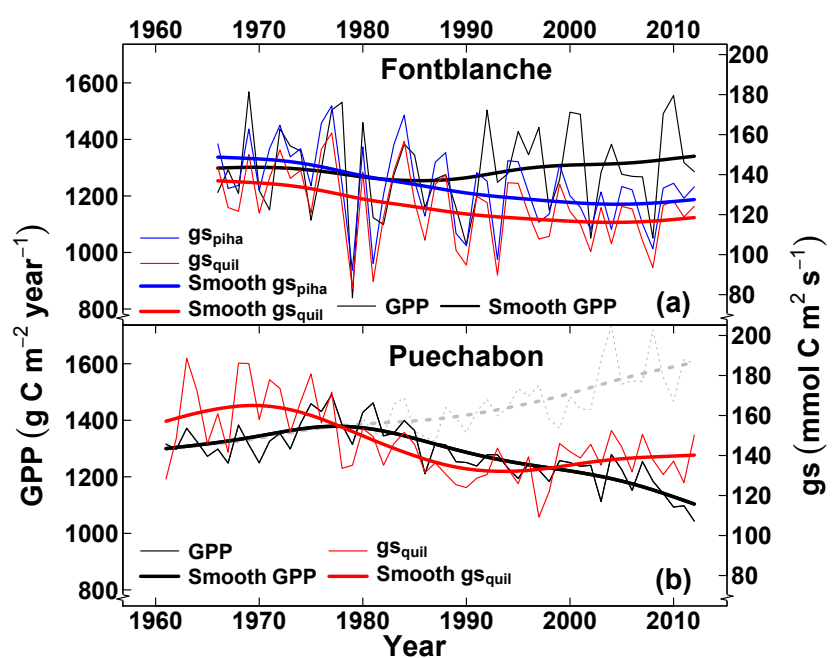

Figure 6. Modelled total annual stand gross primary productivity (GPP) and mean stomatal conductance of sun leaves (gs) for Fontblanche (a) and Puechabon (b) for the period for which meteorological data were available. To show the influence of the precipitation decline observed in Puechabon on GPP, we run a sensitivity simulation in which precipitation was fixed for 1980-2012 on the basis of precipitation in 1960-1979 (Fig. A1) and all other input variables $\left(T_{\min }, T_{\max },\left[\mathrm{CO}_{2}\right]\right)$ were actual values. GPP values from this simulation are depicted as dashed grey lines in (b).

can be related to climatic variability differently from photosynthetic production (Sala et al., 2012). The model showed $\mathrm{C}$ limitation (for primary growth) in the years when $\mathrm{LAI}_{\max }$ was not achieved (i.e. a limitation in LAI is driven by limitations in the $\mathrm{C}$ supply in spring), e.g. all years in Puechabon for the period shown in Fig. A5 (1995-2012) but only those years in Fontblanche when the minimum value considered as a threshold was reached. Therefore, both C-source (photosynthesis) and C-sink (just related to growth; other sinks such as volatile organic compounds or root exudates are not explicitly included in the model) limitations can be assessed in different years within one site and even at different periods within the same year (Millard et al., 2007; Sala et al., 2012; Chen et al., 2013; Fatichi et al., 2014). This hypothesis seems plausible as drought stress affects both C-source (e.g. through reduced stomatal conductance) and C-sink limitations (e.g. cell water turgor, hydraulic performance; McDowell et al., 2013). Whether the pattern of $C$ storage simulated is realistic is something that needs to be validated against actual data. However, the flexible way in which stored $\mathrm{C}$ is modelled has much potential to improve ecosystem models that only view a carbon-source limitation (Sala et al., 2012; Friend et al., 2014).

Water stress is generally considered the greatest limitation for Mediterranean ecosystems, driving a close relationship between precipitation and both growth and photosynthesis (Breda et al., 2006; Pereira et al., 2007; Baldocchi et al., 2010; Gea-Izquierdo and Cañellas, 2014). Our results show

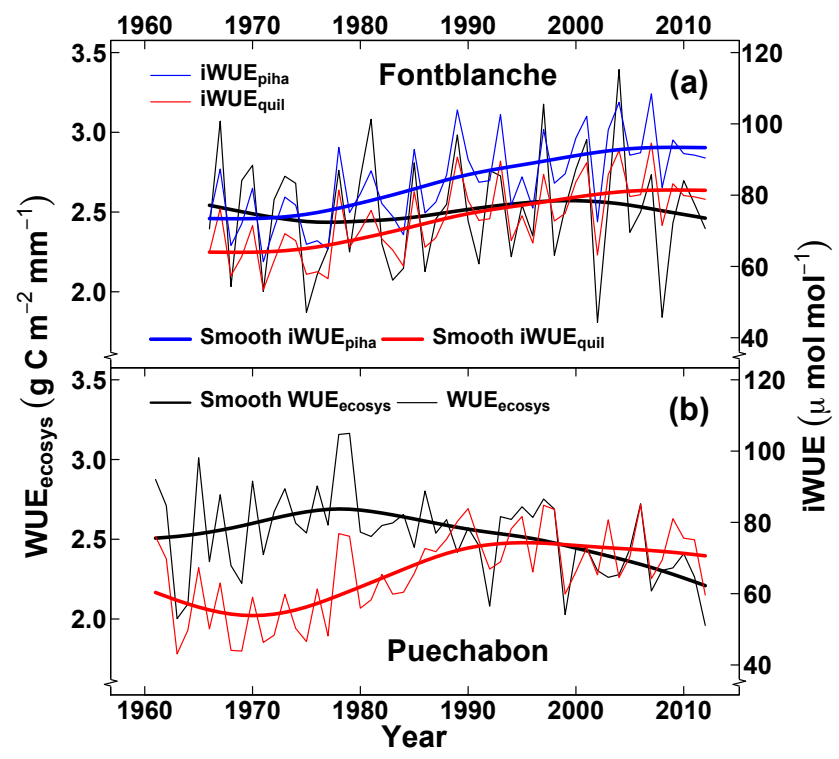

Figure 7. Ecosystem WUE (integral annual) and iWUE for sun leaves (mean daily, for PIHA and QUIL separated in Fontblanche) for (a) Fontblanche and (b) Puechabon for the period for which we had available meteorological data.

that a long-term decrease in precipitation triggered a decrease in simulated GPP at the rainier and coldest site. However, this decline was not expressed in the growth trends. This means that long-term productivity and the allocation of $\mathrm{C}$ to secondary growth were decoupled and did not match (Sala et al., 2012; Chen et al., 2013; Fatichi et al., 2014). The existence of trade-offs between carbon assimilation and allocation in relation to environmental variability suggests exercising caution when using growth as a direct proxy to investigate stand productivity dynamics (e.g. Piovesan et al., 2008; Peñuelas et al., 2008; Gea-Izquierdo and Cañellas, 2014). GPP was greater at the site receiving less precipitation, which could be related to differences in soil retention capacity. However, both soils are calcareous, shallow and stony, and differences in GPP were, to a large part, explained by less limitation for carbon assimilation of low winter temperatures at the warmest site (Fontblanche). They can also be a result of a different species composition (oak vs. pine oak). LAI is greater at the site yielding higher annual GPP. Nonetheless, had this factor been responsible for the observed differences in winter photosynthesis, there would also have been differences in spring photosynthesis, which was not the case (Fig. 3).

A better understanding of the underlying processes determining carbon allocation will benefit process-based models (Sala et al., 2012; Fatichi et al., 2014). Model parameters were within the range found in the literature, bearing in mind that using a daily time step to study differential processes or not distinguishing between leaf ages will affect the scaling of parameters such as $J_{\max }, V_{\text {cmax }}$ or $R_{\mathrm{d}}$ (De Pury and Farquhar, 1997; Grassi and Magnani, 2005; Maseyk et al., 
2008; Vaz et al., 2010). Daily climatic data are readily available on a greater spatial scale than data with a higher temporal resolution, which increases the applicability of daily models. Model performance could be improved by addressing respiration changes related to ontogeny, allometry and nutrient limitations (e.g. N/P) on photosynthesis or by including more complex upscaling of leaf-level photosynthesis (Niinemets et al., 1999; Niinemets, 2007; Chen et al., 2013; McMurtrie and Dewar, 2013). However, it is difficult to find suitable data to calibrate such processes. Similarly, it would be challenging to include allocation to reproductive effort in the carbon budget. This is because, even if it is influenced by water stress in the studied forests (PérezRamos et al., 2010), there is still great uncertainty regarding the causal factors driving multi-annual variability in fruit production (Koenig and Knops, 2000). Addressing stand dynamics would also help to generalize model applicability. Stand disturbances modifying stand competition can leave an imprint on growth for more than a decade whereas they do not seem to affect stand GPP over more than 1 or 2 years if the disturbance is moderate (Misson et al., 2005; Granier et al., 2008). In response to changes in competition, the trees modify the carbon allocation pattern or keep the root : shoot ratio constant to enhance productivity on a per-tree basis but up to an asymptotic stand GPP. Still, the model behaviour was good compared with other studies that addressed ontogenic changes in the carbon allocation response to photosynthesis (Li et al., 2014) and similar or better than that of other mechanistic approaches calibrated to standardized dendroecological data (Misson et al., 2004; Evans et al., 2006; Gaucherel et al., 2008; Tolwinski-Ward et al., 2011; Touchan et al., 2012).

\subsection{Forest performance in response to recent climate change and $\left[\mathrm{CO}_{2}\right]$ enhancement}

Few studies under natural conditions have observed a net increase in growth rates in response to enhanced $\left[\mathrm{CO}_{2}\right]$ levels since the late $1800 \mathrm{~s}$, meaning that other factors, such as water stress and/or $\mathrm{N}$ or $\mathrm{P}$, were more limiting for photosynthesis and/or allocation to growth than $\left[\mathrm{CO}_{2}\right]$ (Niinemets et al., 1999; Peñuelas et al., 2011; McMurtrie and Dewar, 2013; Lévesque et al., 2014). Yet the forests have increased their iWUE. This can be partly a passive consequence of enhanced $\left[\mathrm{CO}_{2}\right]$, but higher iWUE observed in more water-stressed sites suggests that climate is co-responsible for an active acclimation of physiological plant processes (Keenan et al., 2013; Leonardi et al., 2012; Saurer et al., 2014). These processes would include a higher stomatal control, like in our results, where, in turn, we did not observe any increase in longterm carbon assimilation. The mean annual stomatal conductance simulated was driven by climate but also decreased simultaneously in time with increasing $\left[\mathrm{CO}_{2}\right]$ (Fig. A4). Furthermore, there is debate on whether there has been an increase in ecosystem WUE in response to recent changes in $\left[\mathrm{CO}_{2}\right]$ under a warming climate (Beer et al., 2009; Reich- stein et al., 2002; Keenan et al., 2013). In our results the high frequency of WUE followed that of iWUE, but there was some mismatch between the two traits in the low frequency. We observed no dominant time trends in simulated annual WUE for the period 1980-2000 at the site where precipitation remained stable, whereas a decrease in WUE following that in GPP was particularly evident at the site experiencing a drier climate in recent years. This trend was not observed in iWUE, which means that reductions in GPP and $g_{\mathrm{s}}$ were proportionally greater than those in ET (Figs. 6, 7, A3).

Higher $\left[\mathrm{CO}_{2}\right]$ concentrations enhance photosynthesis with the equations used to calculate leaf photosynthesis in biochemical models (e.g. Gaucherel et al., 2008; Keenan et al., 2011; Leonardi et al., 2013; Boucher et al., 2014). Thus, the absence of a long-term increase in GPP and growth would not mean that enhanced $\left[\mathrm{CO}_{2}\right]$ was not beneficial for model outputs (particularly in the case of $\mathrm{C}$-source limitation) but that the net control exerted by other factors such as climatically driven stress was more limiting than that of $\left[\mathrm{CO}_{2}\right]$ availability: growth and photosynthesis would have been lower had we used constant $\left[\mathrm{CO}_{2}\right]$ with the same model parameters. The absence of any modification in the growth trends, even if there are changes in WUE, would express a sink limitation mostly related to hydraulic constraints (Peñuelas et al., 2011; Sala et al., 2012; Keenan et al., 2013). Often, the trees show a growth decline at those sites where there is an enhancement in long-term water stress that dominates species performance (e.g. Bigler et al., 2006; Piovesan et al., 2008; GeaIzquierdo et al., 2014). In contrast, it has been observed that, under certain conditions, trees have increased growth with warming since the 1850s (Salzer et al., 2009; Gea-Izquierdo and Cañellas, 2014). These studies suggest the existence of a positive effect of warming, rather than of $\mathrm{CO}_{2}$ fertilization, upon growth in forests where water stress is not the most limiting factor. Our study sites are located at the northern limit of the Mediterranean region, meaning that the two species studied occupy drier and warmer areas further to the south. The two species have different functional characteristics, e.g. oaks are anisohydric, whereas pines tend to be isohydric. This confers different capacities of adaptation to climate change on them, which means that they should play different roles in future stand dynamics. Our results show the existence of trade-offs in response to climate at different phenological periods. This is important since synergistic environmental stresses acting at different periods can trigger tree mortality (McDowell et al., 2013; Voltas et al., 2013). Model sensitivity analysis could be performed to discuss the influence of specific factors, such as climate or $\left[\mathrm{CO}_{2}\right]$, causing instability in the climate-growth response (D'Arrigo et al., 2008; Boucher et al., 2014). However, $\left[\mathrm{CO}_{2}\right]$ enhancement and climate warming are mixed in analysis performed using data from field studies, which can make the isolation of their effect problematic. The model can be applied using abundant dendrochronological data used to determine the site-dependent parameters. This would provide much flexi- 
bility for investigating growth trends and forest performance in response to global change on a larger scale.

\section{Conclusions}

By developing an original process-based model with carbon allocation relationships explicitly expressed as functions of climate, we accurately simulated gross primary productivity and the allocation of carbon to secondary growth in evergreen Mediterranean forests. Different processes were modelled as functions of environmental variability, including $\left[\mathrm{CO}_{2}\right]$ and climate. The studied forests showed trade-offs in carbon allocation to different plant compartments in response to stress in different seasons: with low temperatures and a short photoperiod in winter and with moisture shortage in summer. We modelled a decreasing time trend in stomatal conductance, which would suggest a partly active increase in iWUE in the forests studied. Interannual variability in WUE followed closely that in iWUE. However, WUE exhibited a decreasing trend at the site where we simulated a decrease in LAI and GPP in response to a decrease in annual precipitation since the 1970s. Long-term GPP has remained at similar levels in the last 50 years in just one stand, whereas it declined in the forest suffering a reduction in precipitation. This suggests different acclimation processes at the canopy level and in the pattern of allocation in response to enhanced xericity and increasing $\left[\mathrm{CO}_{2}\right]$ levels; these acclimation processes could not counterbalance the negative effect of warming only at the site where there was a simultaneous decrease in precipitation. Tree growth was partly decoupled from stand productivity, highlighting that it can be risky to use growth as a direct proxy for GPP. The model is flexible enough to assess both $\mathrm{C}$-source and C-sink limitations and includes a dynamic estimation of stored $\mathrm{C}$. These features would improve ecosystem models with a fixed C-source formulation. By calibrating a limited number of parameters related to carbon allocation, there is great potential for using the model with abundant dendroecological data to characterize past instability in the growth response in relation to environmental variability and to simulate future forest responses under different climatic scenarios. 
Appendix A

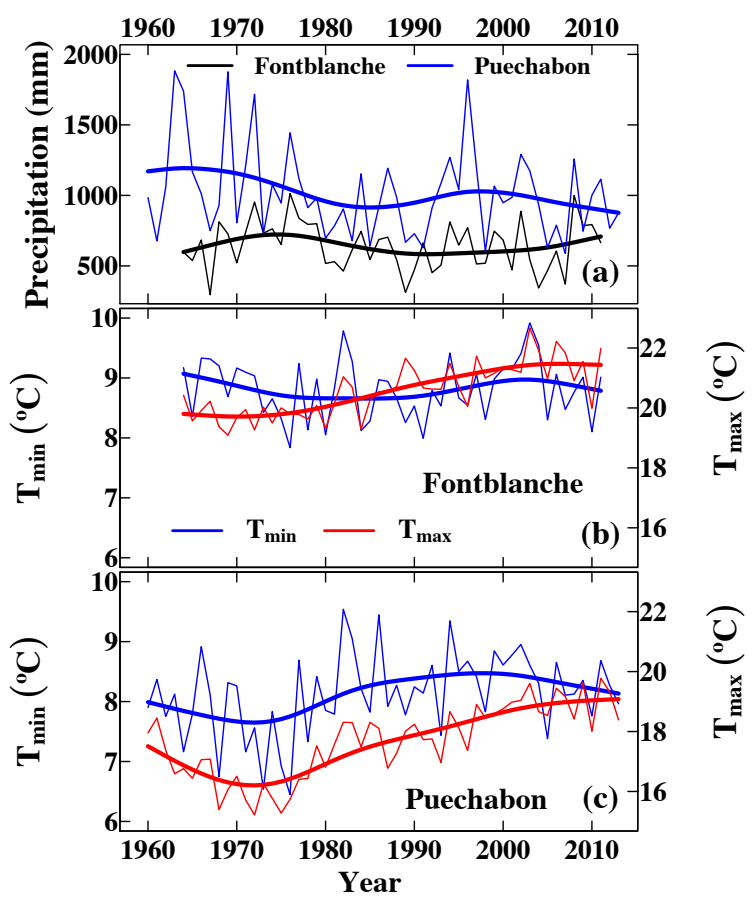

Figure A1. Mean climatic time series of the last 50 years. (a) Annual precipitation; and annual maximum $\left(T_{\max }\right)$ and minimum $\left(T_{\min }\right)$ temperatures for Fontblanche (b) and Puechabon (c).

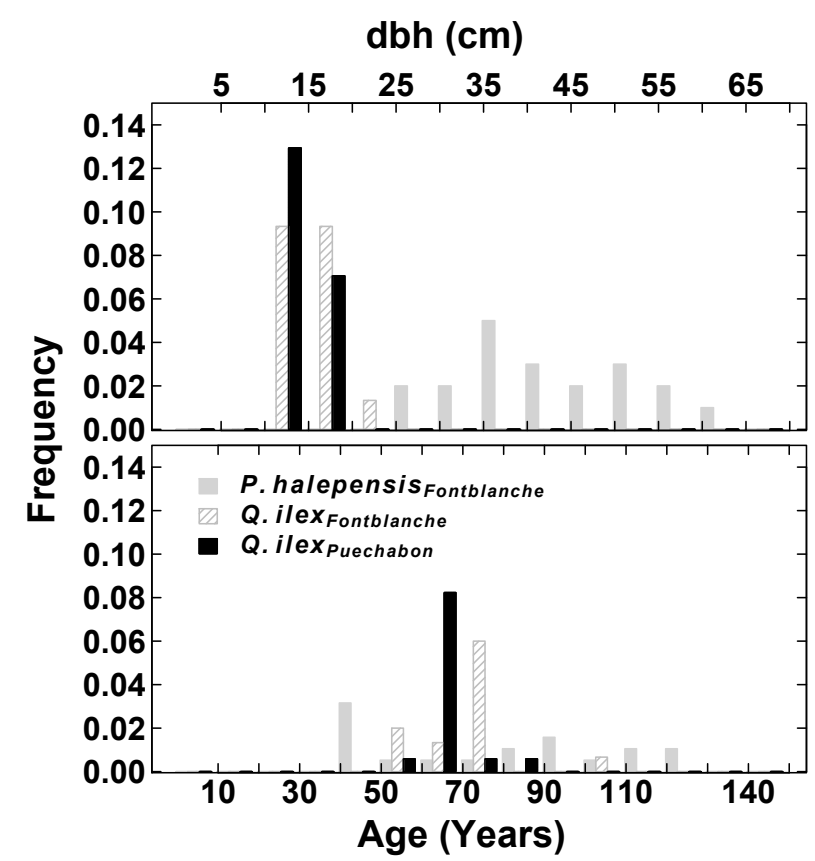

Figure A2. Diameter (dbh, cm) and age (years) distribution of trees included in the chronologies. Frequencies are calculated separately by species and site. 


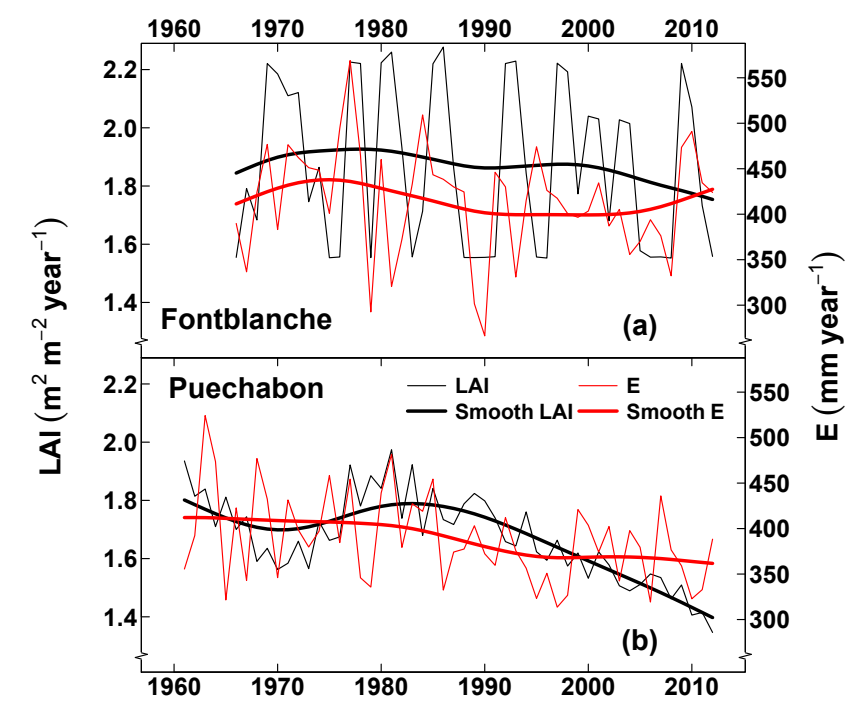

Figure A3. Simulated maximum annual leaf area index LAI $\left(\mathrm{m}^{2} \mathrm{~m}^{-2}\right)$ and total annual stand transpiration $\mathrm{E}\left(\mathrm{mm} \mathrm{yr}^{-1}\right)$ in Fontblanche (a) and Puechabon (b).

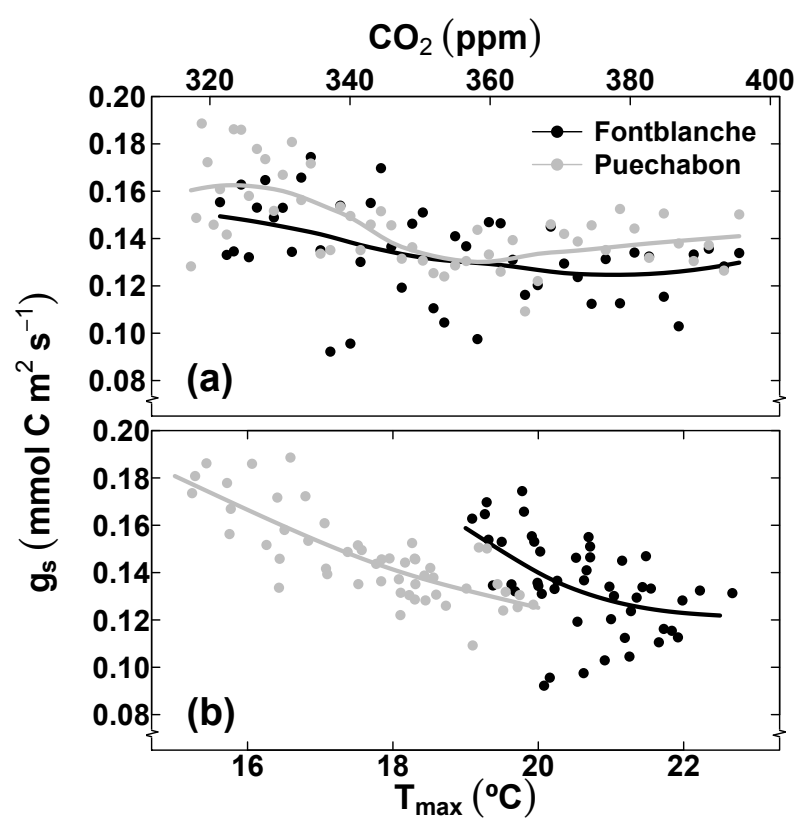

Figure A4. Simulated mean annual stomatal conductance $\left(g_{\mathrm{s}}\right)$ as a function of mean $\left[\mathrm{CO}_{2}\right](\mathbf{a})$ and mean maximum temperature (b). 


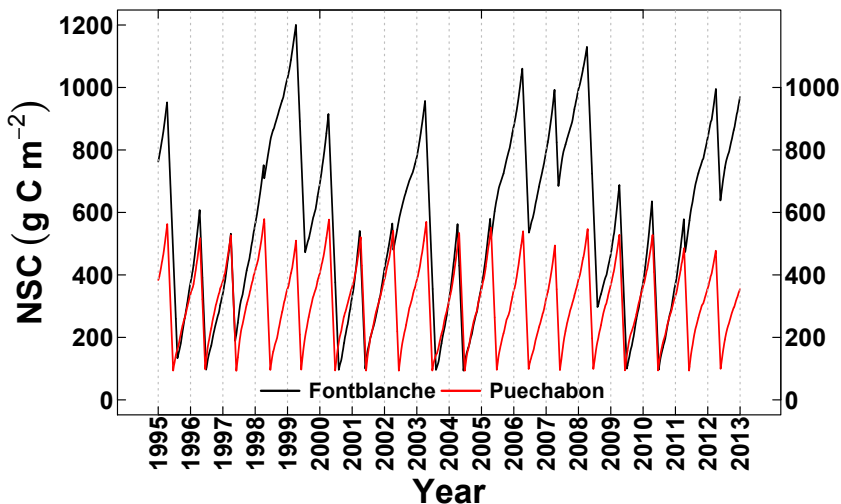

Figure A5. Simulated non-structural carbohydrate content (NSC) in the storage pool at both sites. The period 1995-2012 is shown to highlight within-year variability. 
Acknowledgements. G. Gea-Izquierdo was funded by the Labex OT-Med (no. ANR-11-LABEX-0061) from the "Investissements d'Avenir" program of the French National Research Agency through the A*MIDEX project (no. ANR-11-IDEX-0001-02). Federation de Recherche FR3098 ECCOREV, the labex IRDHEI and OHM-BMP also supported the study. We are grateful to Roland Huc for sharing data from Fontblanche.

Edited by: Akihiko Ito

\section{References}

Allard, V., Ourcival, J. M., Rambal, S., Joffre, R. and Rocheteau, A.: Seasonal and annual variation of carbon exchange in an evergreen Mediterranean forest in southern France, Glob. Change Biol., 14, 714-725, 2008.

Baldocchi, D. D.: Assessing the eddy covariance technique for evaluating carbon dioxide exchange rates of ecosystems: Past, present and future, Glob. Change Biol., 9, 479-492, 2003.

Baldocchi, D. D., Ma, S. Y., Rambal, S., Misson, L., Ourcival, J. M., Limousin, J. M., Pereira, J., and Papale, D.: On the differential advantages of evergreenness and deciduousness in mediterranean oak woodlands: a flux perspective, Ecol. Appl., 20, 1583-1597, 2010.

Beer, C., Ciais, P., Reichstein, M., Baldocchi, D., Law, B. E., Papale, D., Soussana, J.-F., Ammann, C., Buchmann, N., Frank, D., Gianelle, D., Janssens, I. A., Knohl, a., Köstner, B., Moors, E., Roupsard, O., Verbeeck, H., Vesala, T., Williams, C. A., and Wohlfahrt, G.: Temporal and among-site variability of inherent water use efficiency at the ecosystem level, Global Biogeochem. Cy., 23, GB2018, doi:10.1029/2008GB003233, 2009.

Bernacchi, C. J., Singsaas, E. L., Pimentel, C., Portis, A. R., and Long, S. P.: Improved temperature response functions for models of Rubisco-limited photosynthesis, Plant Cell Environ., 24, 253 259, 2001

Bigler, C., Braker, O. U., Bugmann, H., Dobbertin, M., and Rigling, A.: Drought as an inciting mortality factor in Scots pine stands of the Valais, Switzerland, Ecosystems, 9, 330-343, 2006.

Boucher, É., Guiot, J., Hatté, C., Daux, V., Danis, P.-A., and Dussouillez, P.: An inverse modeling approach for tree-ring-based climate reconstructions under changing atmospheric $\mathrm{CO}_{2}$ concentrations, Biogeosciences, 11, 3245-3258, doi:10.5194/bg-113245-2014, 2014.

Breda, N., Huc, R., Granier, A., and Dreyer, E.: Temperate forest trees and stands under severe drought: a review of ecophysiological responses, adaptation processes and long-term consequences, Ann. For. Sci., 63, 625-644, 2006.

Breshears, D. D., Myers, O. B., Meyer, C. W., Barnes, F. J., Zou, C. B., Allen, C. D., McDowell, N. G., and Pockman, W. T.: Tree die-off in response to global change-type drought: mortality insights from a decade of plant water potential measurements, Front. Ecol. Environ., 7, 185-189, 2009.

Chen, G., Yang, Y., and Robinson, D.: Allocation of gross primary production in forest ecosystems: allometric constraints and environmental responses, New Phytol., 200, 1176-1186, 2013.

D’Arrigo, R., Wilson, R., Liepert, B., and Cherubini, P.: On the "Divergence Problem" in Northern Forests: A review of the tree-ring evidence and possible causes, Global Planet. Change, 60, 289305, 2008.

De Pury, D. G. G. and Farquhar, G. D.: Simple scaling of photosynthesis from leaves to canopies without the errors of big-leaf models, Plant Cell Environ., 20, 537-557, 1997.

De Kauwe, M. G., Medlyn, B. E., Zaehle, S., Walker, A. P., Dietze, M. C., Hickler, T., Jain, A. K., Luo, Y. Q., Parton, W. J., Prentice, I. C., Smith, B., Thornton, P. E., Wang, S. S., Wang, Y. P., Warlind, D., Weng, E. S., Crous, K. Y., Ellsworth, D. S., Hanson, P. J., Seok Kim, H., Warren, J. M., Oren, R., and Norby, R. $\mathrm{J}$. : Forest water use and water use efficiency at elevated $\mathrm{CO}_{2}$ : a model-data intercomparison at two contrasting temperate forest FACE sites, Glob. Change Biol., 19, 1759-1779, 2013.

Dickman, L. T., McDowell, N. G., Sevanto, S., Pangle, R. E., and Pockman, W. T.: Carbohydrate dynamics and mortality in a piñon-juniper woodland under three future precipitation scenarios, Plant. Cell Environ., 729-739, 2015.

Evans, M. N., Reichert, B. K., Kaplan, A., Anchukaitis, K. J., Vaganov, E. A., Hughes, M. K., and Cane, M. A.: A forward modeling approach to paleoclimatic interpretation of tree-ring data, J. Geophys. Res., 111, G03008, doi:10.1029/2006JG000166, 2006.

Farquhar, G. D., von Caemmerer, S., and Berry, J. A.: A biochemical model of photosynthetic $\mathrm{CO}_{2}$ assimilation in leaves of $\mathrm{C} 3$ species, Planta, 149, 78-90, 1980.

Fatichi, S., Leuzinger, S., and Körner, C.: Moving beyond photosynthesis: from carbon source to sink-driven vegetation modeling, New Phytol., 201, 1086-1095, 2014.

Flexas, J., Bota, J., Galmes, J., Medrano, H., and Ribas-Carbo, M.: Keeping a positive carbon balance under adverse conditions: responses of photosynthesis and respiration to water stress, Physiol. Plant., 127, 343-352, 2006.

Friedlingstein, P., Joel, G., Field, C. B., and Fung, I. Y.: Toward an allocation scheme for global terrestrial carbon models, Glob. Change Biol., 5, 755-770, 1999.

Fritts, H.C,: Tree Rings and Climate, Blackburn Press, 567 pp., 1976.

Gaucherel, C., Campillo, F., Misson, L., Guiot, J., and Boreux, J. J.: Parameterization of a process-based tree-growth model: Comparison of optimization, MCMC and Particle Filtering algorithms, Environ. Model. Softw., 23, 1280-1288, 2008.

Gea-Izquierdo, G., Mäkelä, A., Margolis, H., Bergeron, Y., Black, T. A., Dunn, A., Hadley, J., Kyaw Tha Paw U, Falk, M., Wharton, S., Monson, R., Hollinger, D. Y., Laurila, T., Aurela, M., McCaughey, H., Bourque, C., Vesala, T., and Berninger, F.: Modeling acclimation of photosynthesis to temperature in evergreen conifer forests, New Phytol., 188, 175-186, 2010.

Gea-Izquierdo, G., Fernández-de-uña, L., and Cañellas, I.: Growth projections reveal local vulnerability of Mediterranean oaks with rising temperatures, Forest Ecol. Manag., 305, 282-293, 2013.

Gea-Izquierdo, G. and Cañellas, I.: Long-term climate forces instability in long-term productivity of a Mediterranean oak along climatic gradients, Ecosystems, 17, 228-241, 2014.

Gea-Izquierdo, G., Viguera, B., Cabrera, M., and Cañellas, I.: Drought induced decline could portend widespread oak mortality at the xeric ecotone in managed Mediterranean pine-oak woodlands, Forest Ecol. Manag. 320, 70-82, 2014. 
Granier, A., Breda, N., Longdoz, B., Gross, P., and Ngao, J.: Ten years of fluxes and stand growth in a young beech forest at Hesse, North-eastern France, Ann. For. Sci., 64, 704, 2008.

Grassi, G. and Magnani, F.: Stomatal, mesophyll conductance and biochemical limitations to photosynthesis as affected by drought and leaf ontogeny in ash and oak trees, Plant Cell Environ., 28, 834-849, 2005

Guiot, J., Boucher, E., and Gea-Izquierdo, G.: Process models and model-data fusion in dendroecology, Front. Ecol. Evol., 2, 1-12, 2014.

Hoff, C. and Rambal, S.: An examination of the interaction between climate, soil and leaf area index in a Quercus ilex ecosystem, Ann. For. Sci., 60, 153-161, 2003.

IPCC: Climate Change: The Physical Science Basis, Summary for policymakers, edited by: Stocker, T. F., Qin, D., Plattner, G.-K., Tignor, M., Allen, S. K., Boschung, J., Nauels, A., Xia, Y., Bex, V., and Midgley, P. M., IPCC, Geneva, Switzerland, 33 pp., 2013.

Keenan, T., Maria Serra, J., Lloret, F., Ninyerola, M., and Sabate, S.: Predicting the future of forests in the Mediterranean under climate change, with niche- and process-based models: $\mathrm{CO}_{2}$ matters!, Glob. Change Biol., 17, 565-579, 2011. Keenan, T. F., Hollinger, D. Y., Bohrer, G., Dragoni, D., Munger, J. W., Schmid, H. P. , and Richardson, A. D.: Increase in forest water-use efficiency as atmospheric carbon dioxide concentrations rise, Nature, 499, 324-7, 2013.

Koenig, W. D. and Knops, M. H.: Patterns of annual seed production by Northern Hemisphere trees: a global perspective, Am. Nat., 155, 59-69, 2000.

Körner, C.: Growth Controls Photosynthesis - Mostly, Nova Acta Leopoldina, 283, 273-283, 2013.

Leonardi, S., Gentilesca, T., Guerrieri, R., Ripullone, F., Magnani, F., Mencuccini, M., Noije, T. V., and Borghetti, M.: Assessing the effects of nitrogen deposition and climate on carbon isotope discrimination and intrinsic water-use efficiency of angiosperm and conifer trees under rising $\mathrm{CO}_{2}$ conditions, Glob. Change Biol., 18, 2925-2944, 2012.

Le Roux, X., Lacointe, A., Escobar-Gutierrez, A., and Le Dizes, S.: Carbon-based models of individual tree growth: A critical appraisal, Ann. For. Sci., 58, 469-506, 2001.

Leuning, R.: A critical appraisal of a combined stomatalphotosynthesis model for C3 plants, Plant Cell Environ., 18, 339-355, 1995.

Lévesque, M., Siegwolf, R., Saurer, M., Eilmann, B., and Rigling, A.: Increased water-use efficiency does not lead to enhanced tree growth under xeric and mesic conditions, New Phytol., 203, 94109, 2014.

Li, G., Harrison, S. P., Prentice, I. C., and Falster, D.: Simulation of tree-ring widths with a model for primary production, carbon allocation, and growth, Biogeosciences, 11, 6711-6724, doi:10.5194/bg-11-6711-2014, 2014.

Limousin, J. M., Rambal, S., Ourcival, J. M., Rocheteau, A., Joffre, R., and Rodriguez-Cortina, R.: Long-term transpiration change with rainfall decline in a Mediterranean Quercus ilex forest, Glob. Change Biol., 15, 2163-2175, 2009.

Limousin, J. M., Longepierre, D., Huc, R., and Rambal, S.: Change in hydraulic traits of Mediterranean Quercus ilex subjected to long-term throughfall exclusion, Tree Physiol., 30, 1026-1036, 2010
Limousin, J.-M., Rambal, S., Ourcival, J.-M., RodriguezCalcerrada, J., Perez-Ramos, I. M., Rodriguez-Cortina, R., Misson, L., and Joffre, R.: Morphological and phenological shoot plasticity in a Mediterranean evergreen oak facing long-term increased drought, Oecologia, 169, 565-577, 2012.

Maseyk, K. S., Lin, T., Rotenberg, E., Grünzweig, J. M., Schwartz, A., and Yakir, D.: Physiology-phenology interactions in a productive semi-arid pine forest, New Phytol., 178, 603-16, 2008.

McDowell, N.G., Fisher, R.A., Xu, C., Domec, J., Höltta, T., Mackay, D.S., Sperry, J. S., Boutz, A., Dickman, L., Gehres, N., Limousin, J.M., Macalady, A., Pangle, R. E., Rasse, D.P., Ryan, M.G., Sevanto, S., Waring, R.H., Williams, A.P., Yepez, E. A., and Pockman, W.T.: Evaluating theories of drought-induced vegetation mortality using a multimodel - experiment framework, New Phytol., 200, 304-321, 2013.

McMurtrie, R. E. and Dewar, R. C.: New insights into carbon allocation by trees from the hypothesis that annual wood production is maximized, New Phytol., 199, 981-990, 2013.

Millard, P., Sommerkorn, M., and Grelet, G. A.: Environmental change and carbon limitation in trees: A biochemical, ecophysiological and ecosystem appraisal, New Phytol., 175, 11-28, 2007.

Misson, L.: MAIDEN: a model for analyzing ecosystem processes in dendroecology, Can. J. For. Res., 34, 874-887, 2004.

Misson, L., Rathgeber, C., and Guiot, J.: Dendroecological analysis of climatic effects on Quercus petraea and Pinus halepensis radial growth using the process-based MAIDEN model, Can. J. For. Res., 34, 888-898, 2004.

Misson, L., Tang, J., Xu, M., Mckay, M. ,and Goldstein, A.: Influences of recovery from clear-cut, climate variability, and thinning on the carbon balance of a young ponderosa pine plantation, Agric. Fore, 130, 207-222, 2005.

Misson, L., Degueldre, D., Collin, C., Rodriguez, R., Rocheteau, A., Ourcival, J.-M., and Rambal, S.: Phenological responses to extreme droughts in a Mediterranean forest, Glob. Change Biol., 17, 1036-1048, 2011.

Montserrat-Marti, G., Camarero, J. J., Palacio, S., Perez-Rontome, C., Milla, R., Albuixech, J., and Maestro, M.: Summer-drought constrains the phenology and growth of two coexisting Mediterranean oaks with contrasting leaf habit: implications for their persistence and reproduction, Trees-Structure Funct., 23, 787-799, 2009.

Niinemets, U.: Photosynthesis and resource distribution through plant canopies, Plant. Cell Environ., 30, 1052-71, 2007.

Niinemets, U. and Valladares, F.: Photosynthetic acclimation to simultaneous and interacting environmental stresses along natural light gradients: optimality and constraints, Plant Biol. (Stuttg), 6, 254-68, 2004.

Niinemets, Ü., Tenhunen, J. D., Canta, N. R., Chaves, M. M., Faria, T., Pereira, J. S., and Reynolds, J. F.: Interactive effects of nitrogen and phosphorus on the acclimation potential of foliage photosynthetic properties of cork oak, $Q$. suber, to elevated atmospheric $\mathrm{CO}_{2}$ concentrations, Glob. Change Biol., 5, 455-470, 1999.

Nobel, P. S.: Physicochemical and environmental plant physiology. 4th edn. Academic Press, Elsevier, Oxford UK, 568 pp., 2009.

Peng, C. H., Guiot, J., Wu, H. B., Jiang, H., and Luo, Y. Q.: Integrating models with data in ecology and palaeoecology: advances towards a model-data fusion approach, Ecol. Lett., 14, 522-536, 2011. 
Peñuelas, J., Hunt, J. M., Ogaya, R., and Jump, A. S.: Twentieth century changes of tree-ring delta $\mathrm{C}-13$ at the southern rangeedge of Fagus sylvatica: increasing water-use efficiency does not avoid the growth decline induced by warming at low altitudes, Glob. Change Biol., 14, 1076-1088, 2008.

Peñuelas, J., Canadell, J. G., and Ogaya, R.: Increased water-use efficiency during the 20th century did not translate into enhanced tree growth, Glob. Ecol. Biogeogr., 20, 597-608, 2011.

Pereira, J. S., Mateus, J. A., Aires, L. M., Pita, G., Pio, C., David, J. S., Andrade, V., Banza, J., David, T. S., Paço, T. A., and Rodrigues, A.: Net ecosystem carbon exchange in three contrasting Mediterranean ecosystems - the effect of drought, Biogeosciences, 4, 791-802, doi:10.5194/bg-4-791-2007, 2007.

Pérez-Ramos, I. M., Ourcival, J. M., Limousin, J. M., and Rambal, S.: Mast seeding under increasing drought: results from a longterm data set and from a rainfall exclusion experiment, Ecology, 91, 3057-3068, 2010.

Piovesan, G., Biondi, F., Di Filippo, A., Alessandrini, A., and Maugeri, M.: Drought-driven growth reduction in old beech $(\mathrm{Fa}$ gus sylvatica L.) forests of the central Apennines, Italy, Glob. Change Biol., 14, 1265-1281, 2008.

Rambal, S., Joffre, R., Ourcival, J. M., Cavender-Bares, J. , and Rocheteau, a.: The growth respiration component in eddy $\mathrm{CO} 2$ flux from a Quercus ilex mediterranean forest, Glob. Change Biol., 10, 1460-1469, 2004.

Reichstein, M., Tenhunen, J. D., Roupsard, O., Ourcival, J. M., Rambal, S., Miglietta, F., Peressotti, A., Pecchiari, M., Tirone, G., and Valentini, R.: Severe drought effects on ecosystem $\mathrm{CO}_{2}$ and $\mathrm{H}_{2} \mathrm{O}$ fluxes at three Mediterranean evergreen sites: revision of current hypotheses?, Glob. Change Biol., 6, 999-1017, 2002.

Reichstein, M., Tenhunen, J., Roupsard, O., Ourcival, J. M., Rambal, S., Miglietta, F., Peressotti, A., Pecchiari, M., Tirone, G., and Valentini, R.: Inverse modeling of seasonal drought effects on canopy $\mathrm{CO}_{2} / \mathrm{H}_{2} \mathrm{O}$ exchange in three Mediterranean ecosystems, J. Geophys. Res., 108, 4726, doi:10.1029/2003JD003430, 2003.

Reichstein, M., Falge, E., Baldocchi, D., Papale, D., Aubinet, M., Berbigier, P., Bernhofer, C., Buchmann, N., Gilmanov, T., Granier, A., Grünwald, T., Havránková, K., Ilvesniemi, H., Janous, D., Knohl, A., Laurila, T., Lohila, A., Loustau, D., Matteucci, G., Meyers, T., Miglietta, F., Ourcival, J. M., Pumpanen, J., Rambal, S., Rotenberg, E., Sanz, M., Tenhunen, J., Seufert, G., Vaccari, F., Vesala, T., Yakir, D., and Valentini, R.: On the separation of net ecosystem exchange into assimilation and ecosystem respiration: Review and improved algorithm, Glob. Change Biol., 11, 1424-1439, 2005.

Sala, A. and Tenhunen, J. D.: Simulations of canopy net photosynthesis and transpiration in Quercus ilex L. under the influence of seasonal drought, Agric. For. Meteorol., 78 203-222, 1996.

Sala, A., Woodruff, D. R., and Meinzer, F. C.: Carbon dynamics in trees: feast or famine?, Tree Physiol., 32, 764-75, 2012.

Salzer, M. G., Hughes, M. K., Bunn, A. G., and Kipfmueller, K. F.: Recent unprecedented tree-ring growth in bristlecone pine at the highest elevations and possible causes, P. Natl. Acad. Sci., 106, 20348-20353, 2009.
Saurer, M., Spahni, R., Frank, D.C., Joos, F., Leuenberger, M., Loader, N.J., McCarroll, D., Gagen, M., Poulter, B., Siegwolf, R. T. W., Andreu-Hayles, L., Boettger, T., Dorado, I., Fairchild, I. J., Friedrich, M., Gutierrez, E., Haupt, M., Hilasvuori, E., Heinrich, I., Helle, G., Grudd, H., Jalkanen, R., Levanič, T., Linderholm, H. W., Robertson, I., Sonninen, E., Treydte, K., Waterhouse, J. S., Woodley, E. J., Wynn, P. M., and Young, G. H. F.: Spatial variability and temporal trends in water-use efficiency of European forests, Glob. Change Biol., 20, 3700-3712, 2014.

Schaefer, K., Schwalm, C. R., Williams, C., Arain, M. A., Barr, A., Chen, J. M., Davis, K. J., Dimitrov, D., Hilton, T. W., Hollinger, D. Y., Humphreys, E., Poulter, B., Raczka, B. M., Richardson, A. D., Sahoo, A., Thornton, P., Vargas, R., Verbeeck, H., Anderson, R., Baker, I., Black, T.A., Bolstad, P., Chen, J., Curtis, P.S., Desai, A. R., Dietze, M., Dragoni, D., Gough, C., Grant, R. F., Gu, L., Jain, A., Kucharik, C., Law, B., Liu, S., Lokipitiya, E., Margolis, H.A., Matamala, R., McCaughey, J. H., Monson, R., Munger, J.W., Oechel, W., Peng, C., Price, D. T., Ricciuto, D., Riley, W. J., Roulet, N., Tian, H., Tonitto, C., Torn, M., Weng, E., and Zhou, X.: A model-data comparison of gross primary productivity: Results from the North American Carbon Program site synthesis, J. Geophys. Res., 117, G03010, doi:10.1029/2012JG001960, 2012.

Simioni, G., Durand-Gillmann, M., and Huc, R.: Asymmetric competition increases leaf inclination effect on light absorption in mixed canopies, Ann. For. Sci., 70, 123-131, 2013.

Sun, Y., Gu, L., Dickinson, R. E., Norby, R. J., Pallardy, S. G., and Hoffman, F. M.: Impact of mesophyll diffusion on estimated global land $\mathrm{CO}_{2}$ fertilization, P. Natl. Acad. Sci. USA, 111, 15774-15779, 2014.

Tolwinski-Ward, S. E., Evans, M. N., Hughes, M. K., and Anchukaitis, K. J.: An efficient forward model of the climate controls on interannual variation in tree-ring width, Clim. Dyn., 36, 2419-2439, 2011.

Touchan, R., Shishov, V. V., Meko, D. M., Nouiri, I., and Grachev, A.: Process based model sheds light on climate sensitivity of Mediterranean tree-ring width, Biogeosciences, 9, 965-972, doi:10.5194/bg-9-965-2012, 2012.

Vaganov, E. A., Hughes, M. K., and Shashkin, A. V.: Growth Dynamics of Conifer Tree Rings: Images of Past and Future Environments, Springer, New York, 354 pp., 2006.

Vaz, M., Pereira, J. S., Gazarini, L. C., David, T. S., David, J. S., Rodrigues, A., Maroco, J., and Chaves, M. M.: Drought-induced photosynthetic inhibition and autumn recovery in two Mediterranean oak species (Quercus ilex and Quercus suber), Tree Physiol., 30, 946-956, 2010.

Voltas, J., Camarero, J. J., Carulla, D., Aguilera, M., Ortiz, A., and Ferrio, J. P.: A retrospective, dual-isotope approach reveals individual predispositions to winter-drought induced tree dieback in the southernmost distribution limit of Scots pine, Plant. Cell Environ., 36, 1435-48, 2013. 